University of Rhode Island

DigitalCommons@URI

Open Access Master's Theses

1986

\title{
Morphology and Crustal Structure of the Kane Fracture Zone Transverse Ridge
}

Lewis J. Abrams

University of Rhode Island

Follow this and additional works at: https://digitalcommons.uri.edu/theses

\section{Recommended Citation}

Abrams, Lewis J., "Morphology and Crustal Structure of the Kane Fracture Zone Transverse Ridge" (1986). Open Access Master's Theses. Paper 814. https://digitalcommons.uri.edu/theses/814

This Thesis is brought to you for free and open access by DigitalCommons@URI. It has been accepted for inclusion in Open Access Master's Theses by an authorized administrator of DigitalCommons@URI. For more information, please contact digitalcommons-group@uri.edu. 
MORPHOLOGY AND CRUSTAL STRUCTURE OF THE

KANE FRACTURE ZONE TRANSVERSE RIDGE

BY

LEWIS J. ABRAMS

A THESIS SUBMITTED IN PARTIAL FULFILLMENT OF THE

REQUIREMENT FOR THE DEGREE OF

MASTER OF SCIENCE

IN

OCEANOGRAPHY

UNIVERSITY OF RHODE ISLAND

1986 


\section{MASTERS OF SCIENCE THESIS}

OF

LEWIS J. ABRAMS

\section{APPROVED:}

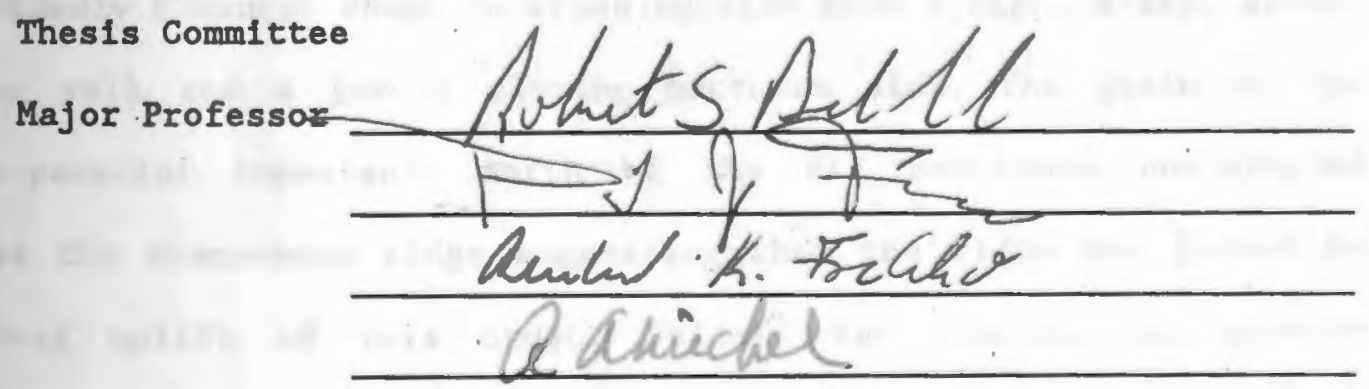

DEAN OF THE GRADUATE SCHOOL 
ABSTRACT

The Kane Fracture Zone (KFZ) Transverse Ridge is an anomalously shallow ridge which parallels the $\mathrm{KFZ}$ for over 200 kilometers east of its intersection with the Mid-Atlantic Ridge rift valley. Sea Beam bathymetry and gravity data have been used to determine the morphology and density structure of the ridge, and travel-time data from two seismic refraction experiments have been used to constrain its seismic velocity structure. The transverse ridge first appears on older 1ithosphere opposite the eastern ridge-transform intersection (RTI). It rises to a maximum height of about $2000 \mathrm{~m}$ above the bordering $\mathrm{KFZ}$ trough $40 \mathrm{~km}$ east of the intersection area. Although bathymetry data along the western 1imb of the $\mathrm{KFZ}$ are relatively sparse, a ridge of similar dimensions appears to be absent. The KFZ transverse ridge has a decidedly flexural shape in cross-section with a high, steep, southfacing wall and a gently sloping northern side. The grain of the ridge-parallel topography north of the $\mathrm{KFZ}$ continues undisrupted across the transverse ridge suggesting that the ridge has formed by vertical uplift of this crust. Seismic ray tracing and gravity analyses indicate that the $\mathrm{KFZ}$ transverse ridge is not locally compensated by an overthickened crust, but is underlain by crustal thicknesses and velocities similar to that of normal oceanic crust on either side of the KFZ. Anomalously thin crust is present only paediately beneath the KFZ trough and the south-facing wall of the txansverse ridge. These constraints, and the existence of the transverse ridge on the older plate, preclude several previously proposed models for its origin including flexural bending due to 
differential subsidence across the fracture zone, constructional volcanism and serpentine diapirism. Although no other single mechanism provides a completely satisfactory explanation for the origin of the $\mathrm{KFZ}$ transverse ridge, the most likely mechanism appears to be a combination of thermal and viscodynamic forces operating near the RTI. 
ACKNOWLEDGEMENTS

First I thank Dr. Robert S. Detrick for his guidance and support throughout this study. I also thank Drs. P. Jeff Fox and Robert S. Detrick for the many invaluable insights, suggestions and reviews that made this manuscript possible and finally, for the opportunity to participate on several of their geophysical cruises. I am indebted to Dr. Charles Barton for both his interest in my progress and the financial support he provided during my first year of graduate study. John Madsen, Dr. C.S. Chiang and Nancy Adams were all generous with their time and expertise concerning various aspects of computer programming, data reduction and data presentation on the Prime/780 and Vax/750 computer systems. I benifited from many disscusions with Dave Gallo, John Madsen and Dr. Mike Sundvik and I thank Throb Pockalny for "some" of his advice and assistance with bathymetric map construction, basketball, football and happy hours. I am greatful to Claire Sherman for juggling all the administrative paper work involved in the care and feeding of graduate students. I thank Paddy Boyle and the Kingston Kicks soccer team for all their kindness and help when I first arrived in R.I. and for three great state championship seasons. I am especially greatful to "almost Dr." Nancy Grindlay for her ancouragement, advice and all our theraputic trips to the mountains of New Hampshire. 


\section{PREFACE}

This thesis has been written in manuscript format. It consists of one paper and two appendices. The paper will be submitted for publication to the Journal of Geophysical Research. The appendices contain data not presented in the paper and the location of the Sea Beam data used to construct the bathymetric maps presented in the paper. The Sea Beam bathymetry and gravity data analyzed in this thesis were collected on leg RC-2511 of the R/N Robert C. Conrad with Drs. R.S. Detrick and P.J. Fox as chief scientists. The seismic record sections used to pick first arrival travel times provided by G.M. Purdy, WHOI, and R.S. Detrick, URI and the velocity vs depth solutions of Detrick and Purdy (1980) and Cormier et al, (1984) were used in the seismic ray tracing analysis presented in this thesis. Figure 7 on page 49 from Cormier et al. (1984) was presented because it contributes significantly to the constraints on the crustal structure of the $\mathrm{KFZ}$ transverse ridge. 
TABLE OF CONTENTS

PAGE

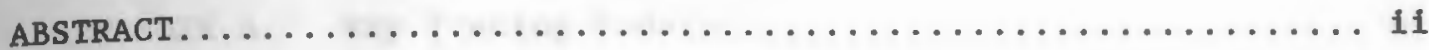

ACKNOWLEDGEMENTS $\ldots \ldots \ldots \ldots \ldots \ldots \ldots \ldots \ldots \ldots \ldots \ldots \ldots \ldots$ iv

PREFACE. . . . . . . . . . . . . . . . . . . . . .

TABLE OF CONTENTS............................ vi

LIST OF FIGURES. .......................... vil

\section{MANUSCRIPT}

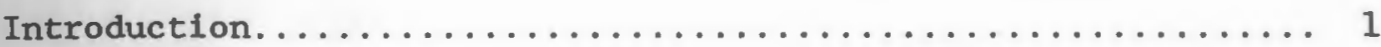

Kane Fracture Zone......................... 3

Morphology

Data Acquisition and Processing................. 6

The Eastern RTI and Adjacent Rift Valley............. 7

The $\mathrm{KFZ}$ and Transverse Ridge................... 8

Important observations...................... 10

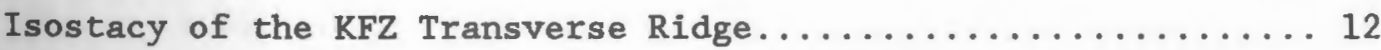

Seismic Structure of the KFZ Transverse Ridge............ 14

Discussion

Thermal Conduction Across Fracture Zones............. 21

Lithospheric Flexure........................ 22

Changes in Relative Plate Motion.................. 24

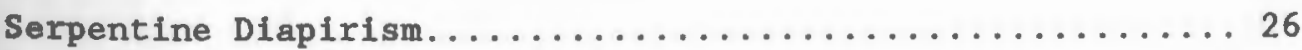

Viscodynamic Forces....................... 28

Conclusions.............................. 30 
Figures................................... 32

References................................... 54

APPENDIX A. Ray Tracing Models.................61

APPENDIX B. Data Storage...................... 68

BIBLIOGRAPHY ................................ 69 


\section{LIST OF FIGURES}

MANUSCRIPT

PAGE

1. Location map of the Sea Beam, gravity and magnetics survey carried out at the Kane fracture zone with the position of $\mathrm{OBH}$ seismic refraction lines.............. 32

2. Sea Beam bathymetric map of a portion of the Kane fracture zone and its eastern intersection with the Mid-Atlantic Ridge............................... 34

3a. Eight Sea Beam swath profiles across the Kane fracture

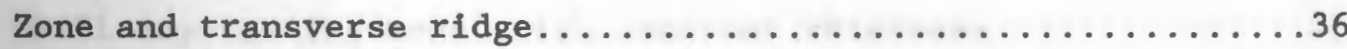

b. Three dimensional perspective display of gridded Sea Beam data of the Kane fracture zone and transverse ridge........38

4. Observed bathymetry across the Kane transverse ridge compared to the shape of a deflected elastic plate.........40

5. Observed and predicted depth vs age profiles along the Kane fracture zone.

6. Observed bathymetry and the corresponding free air gravity and mantle Bouguer anomalies across the Kane fracture Zone and transverse ridge. 
7. Total mantle delay-times for lines shot perpendicular to the Kane Fracture Zone (from Cormier et al., 1983).......46

8 a. ExP81 final ray tracing model for OBH $5 \ldots \ldots \ldots \ldots \ldots \ldots$ b. EXP81 final ray tracing model for oBH $3 \ldots \ldots \ldots \ldots \ldots \ldots$

9. ExP77 final ray tracing model for oBHs 3,4 and $6 \ldots \ldots \ldots 2$

APPENDIX A

A1. EXP81 ray tracing model with constant thickness

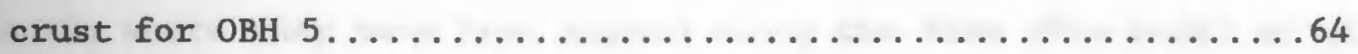

A2. EXP81 ray tracing model with constant thickness

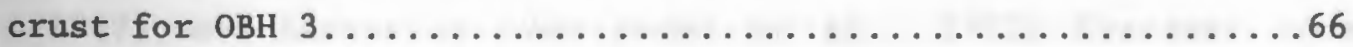


INTRODUCTION

North Atlantic fracture zones, and fracture zones along other slowly spreading ridges, are typically characterized by a zone of strongly lineated terrain, a few kilometers to over thirty kilometers in width, centered about a deep axial trough (Fox and Gallo, 1986). Among the most distinctive topographic features in this zone are linear ridges, towering one or more kilometers above the surrounding sea floor, that border many of these fracture zones for distances of tens or hundreds of kilometers. These features, known as transverse ridges (Bonatti, 1978), are found both within and outside the transform zone. They are particularly prominant in the equatorial Atlantic where they have been mapped along the Vema (Van Andel et al., 1971), Romanche (Bonatti and Honnorez, 1976), St. Paul's (Melson et a1., 1967) and Ascension (Van Andel et al., 1973) fracture zones. However, they also have been reported from other large fracture zones Including the Oceanographer (Fox et al., 1976), Fifteen-Twenty (Collette, 1984), Kane (Purdy et al., 1979), Atlantis (Heezen and Tharp, 1965) and Charlie-Gibbs (Olivet et al., 1974) fracture zones in the North Atlantic, the Owen (Bonatti, 1978) fracture zone in the Indian Ocean and the Mendocino (Menard and Chase, 1970) and the Heezen (Lonsdale, 1986) fracture zones in the Pacific.

Fracture zone transverse ridges are of geological interest for several reasons. Their orientation is parallel to fracture zones and is orthogonal to the tectonic grain of normal oceanic crust suggesting an origin that is related to processes associated with the dynamics of ridge-transform-ridge plate boundaries. The ridges are much shallower 
than adjacent sea floor of the same age and appear, in some cases, to have experienced recent and very rapid vertical tectonism. For example, the summit of the Vema transverse ridge, presently $600 \mathrm{~m}$ below sea level, is capped by shallow water limestones that suggest it once was at or near sea level (Bonatti and Honnorez, 1971; Honnorez et al., 1975). Limestones recovered from the Romanche transverse ridge have been dated and indicate subsidence rates of $0.3 \mathrm{~mm} / \mathrm{yr}$, more than an order of magnitude greater than would be expected from the thermal subsidence of the underlying lithosphere (Bonatti et al., 1977). A diverse suite of basaltic, gabbroic, and ultramafic rocks with various degrees of metamorphism and tectonization have been dredged from the steep walls of transverse ridges at many fracture zones leading to the suggestion that the ridges are uplifted blocks that expose the deeper portions of the oceanic crust (Bonatti and Honnorez, 1976).

The origin of fracture zone transverse ridges remain, however, a poorly understood aspect of fracture zone tectonics. In part, this is due to the extremely rugged topography of these ridges which has made them difficult to map using conventional wide-beam echo sounders. In addition, few geophysical constraints exist on the deeper crustal structure of transverse ridges. Gravity studies of the Romanche (Cochran, 1973), Vema (Robb and Kane, 1975) and Kane (Louden and Forsyth, 1982) fracture zones have suggested transverse ridges are associated with a local mass excess, but these interpretations have been complicated by the density contrast associated with the different aged lithosphere juxtaposed at the fracture zone (Sibuet and VeyratPeiney, 1980; Louden and Forsyth, 1976) and the presence of anomalous crustal thicknesses and densities beneath the adjacent fracture zone 
trough (Detrick and Purdy, 1980). Refraction experiments, hampered by the extreme topographic relief associated with transverse ridges, have cencentrated primarily on determining the crustal structure along the fracture zone trough, and with the exception of whitmarsh and Calvert's (1986) work on Hecate Bank along the Charlie-Gibbs fracture zone and the Potts et al., (1986) study of the Vema fracture zone, few seismic constraints exist on the crustal structure of any transverse ridge.

In this paper we present the results of a Sea Beam survey of the Kane fracture zone transverse ridge and a re-analysis of available gravity and seismic refraction data across this feature. Our results indicate that the Kane fracture zone transverse ridge is an uplifted block of essentlally normal oceanic crust that is not locally compensated either by an overthickened crust or unusually low mantle densities. No single mechanism offers a completely satisfactory axplanation for the origin of the Kane fracture zone transverse ridge, but thermalwiscodynamic stresses developed near the ridge-transform Intersection are suggested as possible a mechanism.

\section{Kane Fracture Zone}

The Kane fracture zone (KFZ) is one of the largest and best mapped fracture zones in the central North Atlantic. It has been traced from its left-lateral, $150 \mathrm{~km}$ transform offset of the Mid-Atlantic Ridge (MAR) at $-23^{\circ} 30^{\prime} \mathrm{N}$ out beyond $80 \mathrm{~m} . \mathrm{y}$. old crust on either side of the rift valley (Fox et al.,1969; Rabinowitz and Purdy, 1976; Purdy et al., 1979; Tucholke and Schouten, 1985). The regional bathymetric 
maps compiled from these studies using conventional, wide-beam echo sounding profiles show that near the MAR the KFZ is an anomalously deep, ESE-trending trough that is bordered to the north along its eastern aseismic limb by an unusually high, elongate ridge, which we call the KFZ transverse ridge. This ridge parallels the $\mathrm{KFZ}$ for at least 240 kilometers east of the MAR rift valley.

The KFZ transverse ridge has not been studied in any detail, but it appears to be similar to transverse ridges found along other large Atlantic fracture zones. Rocks recovered from the transform valley walls (Myashiro et al. 1969), the ridge north of the MAR-KFZ intersection (Karson and Dick, 1983), and further west along the KFZ (Fox et al., 1972) include basalt, metabasalts, gabbros, metagabbros and erpentinized ultramafics, similar to the suite of rocks dredged from the flanking walls of other fracture zones including the Vema, Romanche and Owen (Bonatti and Honnorez, 1976, Bonatti and Hamlyn, 1978). Near the eastern ridge-transform intersection of the Kane Transform submersible and deep-towed ANGUS photographic studies show no evidence for recent tectonic activity along the transverse ridge, although reactivated debris slides and relatively recent fault scarps (tndicating a component of vertical tectonism) are present and become more abundant along the northern transform valley wall as the eastern RTI is approached (Karson and Dick, 1983).

This portion of the KFZ, and the MAR rift valley immediately to the south, have been the site of two major seismic refraction experiments (Detrick and Purdy, 1980; Cormier et a1., 1984; Purdy and Detrick, 1986). Three ridge-parallel refraction profiles, one shot within the rift valley south of the Kane and two others which cross 
the KFZ and transverse ridge east of the MAR, all document the presence of normal crustal thicknesses $(5-7 \mathrm{~km})$ which gradually thin as the $\mathrm{KFZ}$ is approached. Anomalously thin, low velocity crust is observed along the $\mathrm{KFZ}$ trough, with extremely thin crust $(<1 \mathrm{~km}$ thick) present beneath the nodal basin at the eastern intersection of the MAR and KFZ. These findings are similar to the seismically anomalous oceanic crust associated with other North Atlantic fracture zones (White et al., 1984). The crustal structure of the KFZ transverse ridge, which borders the fracture zone trough, was not specifically investigated in these studies, although the results suggest that anomalouly thin crust may extend northward beneath at least part of the transverse ridge (Detrick and Purdy, 1980).

Louden and Forsyth (1982) have also analyzed two long ( $300 \mathrm{~km})$ gravity profiles which cross the $\mathrm{KFZ}$ transverse ridge. They report a positive isostatic anomaly over the transverse ridge on one profile which they interpret as evidence for a thinned crust or a high density body within the ridge. However, $65 \mathrm{~km}$ further west a second profile shows no isostatic anomaly over the transverse ridge leading Louden and Forsyth to conclude that there are significant variations in crustal thickness or density occuring throughout the region both along and across the KFZ. Twigt et al., (1983) also report a positive isostatic anomaly over the KFZ transverse ridge where it appears in the eastern North Atlantic Cretaceous Magnetic Quiet Zone.

In the following sections we first present our sea Beam map of the KFZ transverse ridge, the first high-resolution bathymetry map of a fracture zone transverse ridge. We then use this map to provide a tectonic framework for a re-analysis of available gravity and seismic 
pefraction data across the ridge. Finally, we discuss the lications of of our results for various models of the origin of transverse ridges.

\section{MORPHOLOGY OF THE KANE TRANSVERSE RIDGE \\ AND KANE FRACTURE ZONE VALLEY}

\section{Data acquisition and processing}

An elghteen day Sea Beam bathymetry, magnetic and gravity survey of the Kane transform and the Mid-Atlantic Ridge rift valley mmediately to the south was completed in October-November 1984 as part of a pre-drilling site survey for the Ocean Drilling Program (Detrick et al., 1985). Approximately three days of this survey were devoted to mapping the $\mathrm{KFZ}$ transverse ridge and the adjacent fracture zone valley (Fig. 1). Coverage extends from the eastern ridgetransform intersection (RTI) eastward along the KFZ for a distance of about $130 \mathrm{~km}$. Between the RTI and 44030', nearly complete Sea Beam coverage was obtained out to $30 \mathrm{~km}$ on either side of the fracture zone. East of $44^{\circ} 30^{\prime} \mathrm{W}$, Sea Beam coverage consists of three overlapping swaths along the Kane transverse ridge and fracture zone trough with eight equally spaced $\sim 60 \mathrm{~km}$ long profiles oriented Aproximately perpendicular to the KFZ.

Initial post-processing of the Sea Beam data involved plotting the swaths with a 100-meter contour interval at a scale of 60 inches per degree $(1: 75,000)$. For approximately eight hours each day the ship was navigated using the Global Positioning system (GPS) satellite network which has an accuracy of several tens of meters. Outside the GPS window, the ship was navigated by transit satellites 
and dead reckoning. The final ship navigation was determined by adjusting the bathymetry obtained with transit satellites and dead reckoning to the GPS navigated bathymetry where the swaths intersected or overlapped. The adjustments required were typically less than $1 \mathrm{~km}$ on all but a few tracks. Working bathymetric maps with a 20-m contour Interval were then constructed at scales of 81 inches per degree $(1: 50,000)$ or 40 inches per degree $(1: 100,000)$ by hand contouring the swath data and interpolating between swaths where necessary. Final maps at a more managable scale of 20 inches per degree $(1: 200,000)$ and a contour interval of $100-\mathrm{m}$ were then produced.

A color-filled version of the final 100-m contour map of the eastern Kane RTI and the Kane transverse ridge is shown in Fig. 2. The hot colors (yellow, red) represent shallow regions while the cold colors (blues, purple) denote the deeper portions of the map. A more three-dimensional perspective on the relief associated with the Kane transverse ridge is shown in Fig. $3 a$ and $3 b$.

The eastern RTI and adjacent rift valley

The morphology of the Kane transform and the eastern Kane RTI have been described in detall by Pockalny et al. (1986). The topography of the intersection area is dominated by a large closedcontour depression or nodal basin. It is about $10 \mathrm{~km}$ wide at the $5000-\mathrm{m}$ contour and over $6100 \mathrm{~m}$ deep near the center of the basin. To the south, two NNE-trending scarps, each about $500 \mathrm{~m}$ high, define the Mid-Atlantic Ridge rift valley. The rift valley gradually deepens and widens northward toward the RTI. The topography of the northern part of the rift valley is dominated by a NNE-trending median ridge. This Ildge narrows and deepens northward toward the RTI curving slightly to 
the east and wraping around the eastern edge of the nodal basin. Fockalny et al. (1986) interpret this feature as the present location of the neovolcanic zone within the northern rift valley. This ridge exhibits along strike continuity, extends across the entire intersection area, is decorated with a number of small (20-200 m) anically-shaped highs inferred to be volcanic edifaces, and terminates against the base of the precipitous, $1500 \mathrm{~m}$ high northern wall of the KFZ (Karson and Dick, 1983; Pockalny et al., 1986). East of the nodal basin the rift valley walls are relatively deep (3500$4000 \mathrm{~m})$, and characterized by two broad cuspate ridges that plunge and taper as the fracture zone is approached, mimicking the shape of the neovolcanic zone. To the east, these ridges are bounded by a topographic low that has the appearance of a relic nodal basin. West of the RTI a shallow, rectangularly-shaped ridge stands almost $5000 \mathrm{~m}$ above the adjacent nodal basin. This block is characterized by second-order, ridge-axis parallel terrain elements that pinch out to the north along an exceptionally steep ( $-20^{\circ}$ regional slope), $3000 \mathrm{~m}$ high wensorm-parallel scarp.

\section{The Kane fracture zone and transverse ridge}

The Kane transform valley strikes WNW out of the RTI area. The transform valley walls are composed of an alternating sequence of rift valley-parallel ridges which deepen and taper toward the transform, and thtervening troughs that widen into closed-contour depressions along the floor of the transform valley (Pockalny et al., 1986). This ridge-axis parallel accretionary fabric is abruptly truncated by a narrow ( $<6 \mathrm{~km}$ wide) transform tectonized zone. East of the RTI, the fossil trace of the Kane transform is preserved as an anomalously deep 
trough striking $098^{\circ}$. The floor of the fracture zone valley gradually deepens to the east, but several circular or elongate deeps are present that appear to be relict nodal basins (eg. at $44^{\circ} 45^{\prime} \mathrm{W}, 4^{\circ} 23^{\prime} \mathrm{W}$ and at $\left.44^{\circ} \mathrm{W}\right)$. Refraction lines shot along this part of the $\mathrm{KFZ}$ trough Indicate anomalously thin, but variable crustal thicknesses, with the thinnest crust associated with the deepest portions of the fracture zone valley (Cormier et al., 1984). South of the eastern limb of the KFZ, rift yalley-parallel terrain can be traced northward well into the fracture zone valley. The ridges deepen and narrow toward the fracture zone where some of them curve westward into the fracture zone valley in a fashion similar to the present neovolcanic zone. This orphological similarity suggests that this terrain was formed by constructional volcanism in the rift valley and then laterally Eransported to its present position without significant dismemberment by faulting.

The Kane transverse ridge forms the northern wall of the KFZ from the RTI eastward for a distance of over two hundred kilometers (extending eastward beyond the map shown in Fig. 2). It is distinctly asymmetric in cross-section, with a steep south-facing wall that rises as much as $2000 \mathrm{~m}$ above the floor of the fracture zone valley and a more subdued northern flank that slopes down, gradually reaching more normal depths about $15-20 \mathrm{~km}$ north of the $\mathrm{kFZ}$ (Fig. 3). The Eansverse ridge is first observed as a blocky promontory north of the nodal basin at the eastern RTI. It reaches its shallowest depths $(<2300 \mathrm{~m})$ about $40 \mathrm{~km}$ east of the RTI and undulates between high,

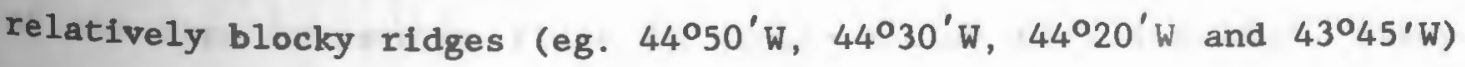
and deeper saddle areas (eg. $44^{\circ} 23^{\prime} \mathrm{W}, 44^{\circ} 10^{\prime} \mathrm{W}$ and $43^{\circ} 50^{\prime} \mathrm{W}$ ). Further 
east, Collette et al. (1984) and Twigt et al. (1983) report that the transverse ridge is absent between $390-36^{\circ} \mathrm{W}$ and reappears Ascontinuously from $36^{\circ}$ to $25^{\circ} \mathrm{W}$. The only major discontinuity in the transverse ridge in the area of Sea Beam coverage occurs $15 \mathrm{~km}$ east of the RTI where a broad rift valley-parallel trough separates two of the shallowest portions of the ridge. The transverse ridge is not physically continuous with the narrow, several hundred meter high median ridge that is found along the eastern half of the transform tectonized zone (Pockalny et al., 1986), although the presence of this ridge marks the first development of anomalous transform-parallel topography along the north wall of the transform valley.

\section{I portant observations}

Three important observations can be made from the Sea Beam data shown in Fig. 2. One of the most striking features is the apparent continuity across the transverse ridge of the ridge axis-parallel teeretionary fabric which characterizes the crust north of the KFZ. The shallower portions of the transverse ridge (eg. the peaks at $44^{\circ} 35^{\prime} \mathrm{W}$ and $\left.44^{\circ} 20^{\prime} \mathrm{W}\right)$ are continuous with topographic ridges on the

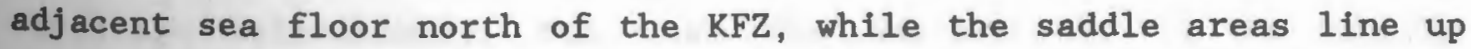
with the corresponding troughs (eg. $44^{\circ} 45^{\prime} \mathrm{W}$ and $44^{\circ} 23^{\prime} \mathrm{W}$ ). The transverse ridge is thus not a continuous, linear transform-parallel ridge which has been built upon the crust north of the KFZ. Instead, to a large extent, it simply appears to be normal MAR ridge and trough tepography which is anomalously shallow near the KFZ.

Another important observation is the distinctly asymmetric shape of the Kane transverse ridge in cross-section with its high, steep south-facing wall and its smaller, gently sloping north side. Figure 
4 shows a composite bathymetry profile constructed by stacking the center beam depths of the eight Sea Beam swaths shown in Fig. 3a. The result is a profile that has a decidedly flexural shape. The observed profile can in fact be modeled by a thin elastic plate with an effective elastic plate thickness of $3-4 \mathrm{~km}$ which has a free end at the fracture zone and is bouyed up from below (Fig. 4). Thus both the maservation of a rift valley-parallel topographic grain across the transverse ridge and its cross-sectional shape are consistent with an origin by some type of vertical tectonism that is focused along the south-facing edge of the fracture zone.

A third important constraint on the origin of the Kane transverse ridge comes from an examination of the variation in depth with age along two profiles north of the KFZ (Fig. 5). These profiles, derived from the Sea Beam map in Fig. 2, are located $\sim 5$ and $15 \mathrm{~km}$ north of the KFZ, respectively. North of the transverse ridge (Profile A), the topography outside the rift mountains follows the predicted depth-age relation of Parsons and Sclater (1977). The crust immediately north of the KFZ (Profile B) also initially subsides along the predicted depth-age relationship, but near the eastern RTI it is rapidly uplifted to form the Kane transverse ridge (The first departure from the expected depth-age relation may occur as early as the middle of the Kane transform, but the major uplift occurs near the eastern RTI.) The maximum uplift, about $1500 \mathrm{~m}$, is not obtained until about $40 \mathrm{~km}$ east of the RTI, afterwhich the ridge appears to subside in parallel with the adjacent sea floor.

The shallowest parts of the transverse ridges observed at the Vema, Romanche and Mendocino fracture zones also occur near RTI 
(Bonatti, 1978, Menard and Chase, 1970). However, large transverse ridges also develop well within the transform offset at some fracture zones (Vema, Romanche,Owen) and, although usually present along only one side of the fracture zone, a few fracture zones are bordered on both sides (Romanche, Alula). Furthermore, large transverse ridges are not confined to slowly-slipping plate boundaries (e.g. Heezen and Tharp fracture zones, Londsdale, 1986). Based on numerous geophysical profiles, Collette et al. (1984) and Collette (1986) observe that a fracture zone morphology consisting of an asymmetric valley to the young side of the fracture zone and a high wall or transverse ridge on the old side can be considered typical of the aseismic limbs of fracture zones in the central North Atlantic. Although the older 1ithosphere opposite the western Kane RTI appears to be uplifted 500$800 \mathrm{~m}$, our limited Sea Beam coverage and bathymetric compilations of the KFZ west of the RTI (B. Tucholke per. comm. 1986) indicate that a large well developed transverse ridge is not present along the western limb of the KFZ.

ISOSTASY OF THE KANE TRANSVERSE RIDGE

As part of the Sea Beam survey, gravity measurements were made using the Conrad's Graf-Askania Gss2 gravimeter which has an accuracy estimated to be $2-5 \mathrm{mGal}$ when used with satellite navigation (tallinger, 1978). We have used these data to place constraints on the density structure and isostasy of the KFZ transverse ridge. 
Free-air gravity anomalies were calculated for each of the eight profiles across the transverse ridge shown in Figure $3 a$. The centerbeam bathymetry and gravity data were projected perpendicular to the transverse ridge (along azimuth $10^{\circ}$ ), resampled at $1.5 \mathrm{~km}$ interval and summed, yielding the averaged profiles shown in Figure 6 . The stacked free air gravity profile, which displays a large positive anomaly ( 40 mGal) over the transverse ridge and a large negative anomaly ( -30 mGal) over the fracture zone trough, is dominated by the effect of the sea floor topography. We therefore calculated what has been referred to as a "mantle Bouguer anomaly" by removing the gravitational effect of the water-crust and crust-mantle boundaries. The calculation was strictly two-dimensional and we assumed a constant crustal thickness of $5 \mathrm{~km}$ and densities of $1.03 \mathrm{gm} / \mathrm{cc}$ for water, 2.70 $\mathrm{gm} / \mathrm{cc}$ for the crust and $3.3 \mathrm{gm} / \mathrm{cc}$ for the upper mantle. Deviations from these assumptions contribute to the calculated mantle Bouguer momaly. Since in this case we are primarily interested in the variations in crustal thickness and density across the fracture zone, we used the technique of Louden and Forsyth (1976) to calculate the variation in mantle density due to the different aged lithosphere on either side of the fracture zone (a $10 \mathrm{~m} . \mathrm{y}$. relative age offset) and also subtracted this effect from the calculated anomaly.

The final corrected mantle Bouguer anomaly is shown in Fig. 6 for both the individual profiles and the stacked profile. A positive anomaly Indicates a relative mass excess, while a negative anomaly fadicates a relative mass deficit. Although there is some variability from profile to profile due to the non-two dimensionality of the trensverse ridge, a (3-17 mGal) positive anomaly is associated with 
the transverse ridge on all the profiles. The existence of this anomaly indicates that the KFZ transverse ridge is not compensated in Airy fashion by an overthickened crust or any other type of low density body (eg. serpentinized peridotite). The ridge is thus not in local isostatic equilibrium and is either associated with anomalously dense "crustal" rocks and or thinner than normal crust.

A broad negative mantle Bouguer anomaly is observed over the $\mathrm{KFZ}$ trough. The existence of a negative anomaly here is somewhat surprising given the unequivocal seismic refraction evidence for monalously thin crust beneath the KFZ valley in this area (Detrick and Purdy, 1980; Cormier et a1., 1984). The gravity data require that this crustal thinning be accompanied by significant reductions in crustal and/or upper mantle densities. Seismic results from the KFZ and other North Atlantic fracture zones are consistent with the presence of a zone, typically $7-17 \mathrm{~km}$ wide, of low-velocity crust within the fracture zone usually attributed to the highly fractured nature of the crust as well as to the accumulation of material from mass wasting (White et al., 1984, Detrick et al., 1982, Karson and Dick, 1983, OTTER 1984a, 1984b).

\section{SEISMIC STRUCTURE OF THE KFZ TRANSVERSE RIDGE}

Two major seismic refraction experiments have been carried out along this portion of the KFZ by Detrick and Purdy (1980) and Cormier et al. (1984). These complementary experiments, referred to respectively as EXP77 and EXP81 in the following discussion (see Fig. 1). document the presence of a narrow zone of anomalously thin crust 
(2-3 km thick) beneath the fracture zone trough adjacent to the KFZ txansverse ridge. They also provide several well-constrained aterminations of the thickness and velocity structure of the crust north and south of the KFZ. In the analysis of the results from both meximents an attempt was made to use the variation in mantle delay times on refraction lines shot across the fracture zone to constrain the width of the anomalously thin crust and the crustal structure beneath the transverse ridge (Fig. 7). South of the KFZ, the EXP77 profile shows a gradual decrease in mantle delay times from 1.2 to 1.0 sec, corresponding to a crustal thinning of 0.5 to $1.0 \mathrm{~km}$ over several tens of kilometers toward the fracture zone. Both experiments indicate a large decrease in mantle delay time beneath the fracture zone trough which reflects the presence of a narrow zone of anomalously thin crust. However, the mantle delay times do not increase again north of the $\mathrm{KFZ}$ as would be expected for the msentially normal thickness crust present on this side of the KFZ. Detrick and Purdy (1980) and Cormier et al. (1984) explained these low mantle delay times as a result of high seismic velocities beneath the KFZ transverse ridge due to the northward extension of an elevated Moho beneath at least part of the transverse ridge.

We have reanalyzed the seismic data from these two experiments, in conjunction with the recently acquired Sea Beam and gravity data, to place better constraints on the crustal structure of the KFZ kransverse ridge. The seismic modeling was carried out using the "thooting method" of raytracing (Cerveny et al., 1977) through a twodimensional, laterally variable media. The models incorporated the observed bathymetry (Sea Beam for EXP77 and $3.5 \mathrm{kHz}$ for EXP81) and 
the velocity-depth solutions from OBH's deployed along each profile wablished by Detrick and Purdy (1980) and Cormier et al. (1984). Travel-times were calculated by tracing diving rays through the assumed model and compared with the observed data. The latter were replcked from the original record sections usually to within $+/-0.02$ sec, except for the emergent, longer-range arrivals which have meertainties of up to $0.1 \mathrm{sec}$. Since the observed bathymetry was Ansorporated into the mode1, topographic corrections were not tequired. The model was iteratively adjusted until a satisfactory fit was found between the calculated and observed travel times. Amplitudes were not modeled.

The main limitations of this kind of modeling are the assumption of two-dimensionality and the non-uniqueness of any "best-fit" model, Axticularly the inherent ambiguity between variations in crustal thickness and velocity in modeling travel-time anomalies. The nonuniqueness is somewhat minimized by including many crossing ray paths from instruments deployed at several locations along the profile. The final velocity models for EXP81 and EXP77 are shown in Figs $8 \mathrm{a}, \mathrm{b}$ and 9, with a comparison of the observed and calculated travel times. EXP81 is a $150 \mathrm{~km}$ long 1ine which crosses the $\mathrm{KFZ}$ transverse ridge near $43^{\circ} 25^{\prime} \mathrm{W}$, just beyond the eastern limit of our Sea Beam data (Fig. 1). IIghty shots to two receivers were modeled. The instruments were $\mathrm{OBH}-5$ located $50 \mathrm{~km}$ south of the $\mathrm{KFZ}$ and $\mathrm{OBH}-3$ located in the fracture zone trough. EXP77 is a $60 \mathrm{~km}$ long profile which crosses the fracture zone about $65 \mathrm{~km}$ west of EXP81. Thirty-eight shots to three receivers were modeled on this profile. The instruments were located $16 \mathrm{~km}$ 
south of the $\mathrm{KFZ}(\mathrm{OBH}-3)$, in the fracture zone valley (OBH-4) and 18 $\mathrm{km}$ north of the $\mathrm{KFZ}(\mathrm{OBH}-6)$.

The southern ends of both profiles can be adequately modeled by a 5.6 km thick crust with a typical oceanic velocity structure antially the same as that published for OBH-5 (EXP2) by Cormier et al. (1984). The crust remains nearly constant in thickness to within 10-20 $\mathrm{km}$ of the $\mathrm{KFZ}$. The transition between this relatively normal crust and the anomalously thin crust (2.6-2.9 $\mathrm{km}$ thick) beneath the KFZ trough occurs quite abruptly on EXP77 and somewhat more gradually on EXP81. In both cases this is accomplished by a significant thinning of the low gradient $6.1-7.2 \mathrm{~km} / \mathrm{s}$ refractor associated with layer 3. Within the fracture zone valley the crustal velocities are mausually low and the crustal velocity gradients are $1.5-2.0 \mathrm{~s}-1$ throughout almost the entire crustal section. In order to match the observed travel times at short ranges $(<20 \mathrm{~km})$ south of the $\mathrm{KFZ}$, lower than normal velocities were maintained in the upper crust south of the fracture zone trough (1e. depths greater than $4800 \mathrm{~m}$ ), an Atervation which is consistent with the relatively broad negative mantle Bouguer anomaly associated with the KFZ in Fig. 6.

The crustal structure within the KFZ trough in Figs. 8 and 9 is essentially the same as earlier interpretations of these data by Datrick and Purdy (1980) and Cormier et al. (1984) and similar to pablished results from other North Atlantic fracture zones (White et a1., 1984). The crustal structure of the KFZ ridge is primarily mastrained by the travel-times of shots over the ridge recorded at OBH-3 (EXP81 and EXP77), OBH-4 (EXP77) and OBH-6 (EXP77). A major Bource of error in matching these arrivals is the precipitous 
copography across the ridge. While none of our models match the observed arrivals exactly, some potential models can definitely be 1iminated. For example, the arrival times of shots more than $20 \mathrm{~km}$ north of the KFZ recorded by $\mathrm{OBH}-3$ in EXP81 and the shots over the $\mathrm{KFZ}$ ridge recorded by $\mathrm{OBH}-3$ in EXP77, preclude the existence of a wotantially overthickened crust beneath the transverse ridge or musually low mantle velocities. Rather, the elevated Moho present under the KFZ trough must extend northward underneath the transverse ridge. The thinnest crust beneath the transverse ridge occurs under the south-facing wall, but because of the height attained by the ridge the total crustal thicknesses increase beneath the ridge apex becoming only about $1 \mathrm{~km}$ less than that which is typical of normal oceanic crust. For example, beneath the apex of the KFZ transverse ridge $(\sim 8$ km north of the fracture zone trough) the total crustal thickness is $4.3 \mathrm{~km}$ in the EXP77 model and $5.1 \mathrm{~km}$ in the EXP81 model, whereas crustal thicknesses over $50 \mathrm{~km}$ to the south are $5.2 \mathrm{~km}$ for EXP77 and $6.25 \mathrm{~km}$ for EXP81. The width of the elevated Moho is about $20 \mathrm{~km}$ for EXP77 and nearly $30 \mathrm{~km}$ for EXP81. Normal crustal thicknesses and Moho depths are again present north of the transverse ridge. The velocity structure of the crust comprising the transverse ridge is generally similar to normal oceanic crust in that it appears to have a low gradient zone with layer 3-type velocities and a well-developed crustmantle boundary. The south wall of the transverse ridge is characterized by relatively high upper crustal velocities (4.5-4.8 $\mathrm{km} / \mathrm{s}$ ), especially in comparison with the anomalous crust in the fracture zone trough imediately to the south. 
Some uncertainties are present in these models. We have assumed an upper mantle velocity gradient of $.06 \mathrm{~s}^{-1}$ but most of the geometric ray paths either do not sample the upper mantle or travel in the upper mantle for such a short distance that a different velocity gradient could not be resolved on the basis of travel-time alone. A large travel-time mismatch occurs at $5-7 \mathrm{~km}$ range on either side of $\mathrm{OBH}-3$ (EXP81) which is probably attributable to bathymetric errors. The fit to the data from OBH-3 (EXP81) south of the $\mathrm{KFZ}$ at $7-15 \mathrm{~km}$ range could also be improved by extending the low crustal velocities in the fracture zone trough further south. However, this would worsen the fit to the arrivals from OBH-5. Similarly, the arrivals at $\mathrm{OBH}-5$ could be fit better by widening the zone of thin crust associated with the KFZ trough, but this would increase the errors in fitting the arrivals from $\mathrm{OBH}-3$. The same process of travel time matching was also applied to the three OBHs of EXP77, therfore these raytracing models are not the best fit possible for individual oBHs, rather they represent a combined best fit.

Despite these uncertainties, the seismic data clearly require a broad zone, 20-30 $\mathrm{km}$ wide, of elevated Moho beneath the $\mathrm{KFZ}$. The thinnest, most anomalous crust occurs in a narrow zone beneath the fracture zone valley. The KFZ transverse ridge is not associated with a thick crustal root. The crustal thicknesses beneath the ridge are 1-1.5 $\mathrm{km}$ less than normal and seismic velocities are much more imilar to those of most oceanic crust. 


\section{DISCUSSION}

The bathymetry, gravity and seismic data presented above provide fiportant constraints on possible mechanisms for the formation of the KFZ transverse ridge and other similar features. Among the most inportant observations are:

(1) the location of the transverse ridge on the older plate bordering the fracture zone

(2) the apparent continuity of the accretionary fabric of normal oceanic crust across the transverse ridge

(3) the flexural shape of the ridge in cross-section

(4) the similarity in uplift of older seafloor opposite both RTIs, but the apparent development of a transverse ridge only along the eastern limb of the $\mathrm{KFZ}$

(5) the absence of a deep crustal root or anomalously low mantle densities beneath the transverse ridge

(6) the presence of relatively normal seismic velocities with thinner than normal crustal thicknesses for the transverse ridge.

These observations, together with the exposure of a diverse suite of crustal and upper mantle-type rocks along the walls of the KFZ, are not consistent with the formation of the ridge by constructional vicanism. Instead, the KFZ transverse ridge appears to have formed by some type of tectonic uplift localized along the fracture zone. Bonatti (1978) reached a similar conclusion after reviewing data from several large equatorial Atlantic and Indian Ocean fracture zones and Alscussed several mechanisms that could potentially explain this uplift. Whitmarsh and Calvert (1986) and Louden et al. (1986) also 
consider the transverse ridges bordering both the Charlie-Gibbs and the Vema fracture zones to be products of tectonic uplift (the Vema and Charlie-Gibbs transverse ridges also appear to be similar in velocity structure and profile to the Kane transverse ridge, although the details of topographic similarities are unknown and the location of these transverse ridge with respect to the RTI are different). Collette and colleagues (Collette et al., 1984 and Collette, 1986) observe that the cross-sectional morphology of the KFZ valley and KFZ transverse ridge (ie. a fracture zone valley flanked by a high wall or transverse ridge located on the old side of the fracture zone) can be considered typical of other fracture zones in the central North Atlantic and they offer a model to explain this morphology. The uplift mechanisms and models presented by Bonatti (1978) and Collette (1986) cover a wide range of possibilities. In the following sections we discuss these and other potential mechanisms and evaluate them in light of our results from the KFZ transverse ridge.

\section{Therial conduction across fracture zones}

The initial uplift of the KFZ transverse ridge appears to occur opposite the intersection of the MAR and the KFZ. The highest levations of the Vema and Romanche transverse ridges also occur on the older plate opposite or near their respective ridge-transform intersections (Bonatti, 1978). This observation suggests that some of the elevation associated with these transverse ridges may be roleted in some way to lateral conduction of heat across the fracture zone. The thermal effect of the juxaposition of a spreading center against older lithosphere has been modeled by Morgan and Forsyth 
(1986). They found that the thermal contrast across a 10 my ageoffset transform (comparable to the Kane) could produce 200-300 m of uplift of the older sea floor. The maximum uplift is not located opposite the RTI, but is swept along with the older lithosphere to a point about $30-40 \mathrm{~km}$ east of the RTI. The pattern of the predicted uplift and the position of the maximum relief match the shape of the KFZ transverse ridge relatively well, but the observed uplift is Mroximately three times the predicted amount. A similar observation was made by Bonatti (1978) who noted that the elevation of the Vema and Romanche transverse ridges are much too large to be explained solely by horizontal heat conduction across the fracture zone. This mechanism cannot be the only process because it fails to explain why transverse ridges are not found at all ridge-transform intersections and why these ridges remain elevated above the surrounding sea floor long after the ridge has been carried out onto the ridge flanks. However, relative highs do exist opposite the western Kane and eastern Vema RTIs and though these ridges do not attain the same dimensions as the ridges opposite the complementary RTIs, their relief may reflect uplift due to horizontal heat conduction across an RTI.

\section{Ththospheric flexure}

Sandwell and Schubert (1982) and Sandwell (1984) have proposed a thermomechanical model for the development of fracture zone topography outside the transform zone. In their model, the upper portion of the liGhosphere is an elastic layer that grows in thickness as the 11 hosphere cools and subsides. They assume that vertical slip does not occur along the fracture zone outside the transform zone. As the lithosphere on the shallower, younger side of the fracture zone cools 
more rapidly than the deeper lithosphere cn che older side, stresses develop along the fracture zonc Ihose stresses flex the elastic layer forming a ridge on the younger side of the fracture zone and a longer yavelength, smaller amplitude trough on the older side. Although this model matches the topography and geoid anomalies associated with some Pacific fracture zones (e.g. the Mendocino fracture zone), it cannot explain the transverse ridges associated with most Atlantic fracture zones which are generally located on the older side of the fracture zone.

Collette and colleagues (Collette et al., 1984, Collette, 1986) propose that transverse ridges form along the transform boundary where upwelling occurs in response to the void created by the horizontal thermal contraction of cooling lithosphere. In reaction to the upward pressure created by upwelling asthenosphere, the lithosphere bounding the transform is flexed upward. Upon leaving the transform the uplifted wall is "joined" to the young oceanic lithosphere which remains depressed by the load of the older uplifted fracture zone wa11, thus creating Collettes' "typical" fracture zone morphology. This model infers that transverse ridges should be ubiquitous Ceatures along large offset transforms. Transverse ridges, however, are opserved along only one side of some transform offsets (e.g. Vema, deanographer, Charlie Gibbs), while along the Kane transform no transverse ridges are observed (Pockalny et al. 1986, this paper), Instead the uplift of older lithosphere occurs opposite the astern Kane RTI where uplifted seafloor does attain a flexural crosssectional shape. Thus, although the KFZ transverse ridge has a (lexural shape in cross-section, differential subsidence across the 
fracture zone or asthenospheric upwelling causing the uplift of lichosphere along both sides of the transform are not viable achanisms for its formation.

Changes in relative plate motion

Bonatti (1978) has noted that the combination of compressional and extensional forces due to changing relative plate motions could be an important cause of vertical tectonic motions along the transform portion of fracture zones. Such readjustments in spreading direction have been documented for both the Vema and Romanche fracture zones (Van Andel et al., 1971, Gorini, 1977). Thicker lithosphere opposite the RTI of large-offset fracture zones may resist changes in transform geometry allowing significant stresses to accumulate along the transform. Compressional bending of the lithosphere adjacent to the transform may explain both the uplift of blocks of crustal and upper wantle material to form transverse ridges along a flank of the transform and the apparent flexural shape of some of these features. Horeover, to allow vertical tectonism on only one side of a fracture zone (e.g. Vema, Owen) Bonatti (1978) invokes a local adjustment in preading direction on one side of the transform not associated with a pole of relative motion change.

A long history of changes in spreading direction have been decumented along the $\mathrm{KFZ}$ from studies of the changing azimuth of its Aracture zone topography (Fox et al., 1969; Rabinowitz and Purdy, 1976; Purdy et al., 1979; Collette et al., 1984, Tucholke and schouten, 1985). Collette (1986) and (Tucholke per. comm. 1986) both note the apparent association of transverse ridges with changes in the arimuth of the eastern limbs of both the Kane and Fifteen-Twenty fracture zones. 
Could a recent change in plate geometry explain the uplift of the KFZ transverse ridge? Sea Beam maps of the KFZ presented in this paper and in Pockalny et al. (1986) indicate the most likely location of the transform fault zone lies along an azimuth (098 ) that is in close agreement with the orientation of North American-African relative plate motion $\left(100^{\circ}\right)$ predicted by Minster and Jordan (1978). This same azimuth also matches the position of the KFZ trough atremely well for at least $130 \mathrm{~km}$ east of the MAR (Fig. 2). The only exception is just east the RTI where the deepest portion of the fracture zone valley bends northward around the northern end of the two arcuate ridges that extend into the fracture zone. While this could represent a recent change in spreading direction, a similar bend is not observed in our Sea Beam data at the western RTI (Pockalny et al., 1986). We believe the arcuate ridges are constructional volcanic features that have overprinted the trace of the original transform and that the KFZ has not experienced a major change in relative plate motion over the past 10 my.

The Sea Beam data thus do not provide evidence for a major, recent change in spreading direction along the Kane transform that could explain the uplift of the KFZ transverse ridge. In addition, the expected development of transverse ridges along the western 1 imb of the $\mathrm{KFZ}$ in a position complemetary to the azimuth changes and ridge mearances along the eastern $\mathrm{KFZ}$ limb are not observed (Tucholke per. comin. 1986).

It may be aignificant that the regional trend of the MAR rift valley south of the $\mathrm{KFZ}$ is nearly $\mathrm{N}-\mathrm{S}$ and thus not orthogonal to the Kane tansform, even though the trends of tectonic and volcanic 
features within the rift valley are oriented more north-northeastly (Kong et al., in prep; Schulz et al., in prep.). This contrasts with the rift valley segment north of the $\mathrm{KFZ}$ which has a clear NNE-trend, perpendicular to the Kane transform. If the spreading direction south of the KFZ is approximately E-W, then the ESE-trending fracture zone east of the southern ridge segment may be in compression, possibly mplaining the uplift of the $\mathrm{KFZ}$ transverse ridge. If the northern ridge segment is still spreading along an azimuth of $100^{\circ}$, as pedicted by Minster and Jordan (1978), then the KFZ west of the MAR will be in extension, rather than compression, explaining the absence of a transverse ridge on that side of the fracture zone. Although this explanation is plausible geometrically, it requires the episodic occurence of compression and the buckling of the older, colder and presumably more rigid lithosphere on the north side of the fracture zone, instead of the weaker plate to the south, to form the transverse ridge which would be somewhat surprising, if not unlikely.

\section{serpentine diapirism}

The abundant exposure of ultramafics and serpentinites on transverse ridges has led to the suggestion that these ridges have formed by the protrusion of partially serpentinized ultramafic diapirs (Zonatti, 1976; Bonatti and Hamlyn, 1978, Francis, 1981)). In this model it is envisioned that sea water circulating through the thin and highly fractured crust within the fracture zone serpentinizes upper mantle peridotite, lowering its density below that of the overlying crustal and upper mantle rocks. The resulting gravitational instability leads to the formation of a serpentine diapir which matrudes the overlying crust, uplifting the transverse ridge. 
The uplift of approximately $2000 \mathrm{~m}$ observed for the KFZ transverse ridge would require the complete serpentinization of over 6 $\mathrm{km}$ of upper mantle to a density of $2.55 \mathrm{gm} / \mathrm{cm} 3$. Laboratory masurements indicate that serpentinization also significantly reduces compressional wave velocities with 1008 serpentinization resulting in velocities as low as $3-4 \mathrm{~km} / \mathrm{s}$ (Fox et al., 1972; Christensen, 1972). Densities and velocities could be substantially higher if the degree of mentinization were less, but the amount of mantle material involved would have to be correspondingly larger. We have no evidence from either the gravity or seismic data across the KFZ transverse ridge for the low densities and seismic velocities required by this model. The $\mathrm{KFZ}$ ridge has relatively high seismic velocites, comparable to normal oceanic crust, and is associated with a mass excess, rather than a mass deficit. The serpentine diapirism model is mesentially a local compensation mechanism and the KFZ ridge is not locally compensated. Thus diapirism on a scale necessary to form the $\mathrm{KFZ}$ transverse ridge is not consistent with the available geophysical data.

Whitmarsh and Calvert (1986) reached a similar conclusion after asalyzing gravity and seismic data across Hecate Bank along the Charlie-Gibbs fracture zone while Potts et al. (1986) using seismic refraction data established the presence of essentially normal oceanic crust beneath the Vema transverse ridge without a zone of serpentinite Mapirism. The existence of high densities within a few kilometers of the sea floor at the Vema transverse ridge (Robb and Kane, 1975) is similarly hard to explain by serpentine diapirism. The crust is sufficiently thin in and near fracture zones that the serpentinites 
axposed on transverse ridges may have been either altered in situ or tqueezed up from relatively shallow depths along the faults bordering the ridge. Tranverse ridges clearly represent uplifted blocks of erustal and upper mantle material, but the source of this uplift must be some other mechanism.

\section{Hacodynamic forces}

The uplift of the $\mathrm{KFZ}$ transverse ridge near the intersection of the KFZ and the MAR suggests the possibility that viscodynamic forces associated with upwelling of asthenospheric material beneath the adjacent spreading axis may play a role in its origin. Initial Noodynamic uplift of the KFZ ridge is consistent with our gravity results which indicate the ridge is not in isostatic equilibrium. Sleep and Biehler (1970) first suggested that the existence of nodal basins at RTI could be explained dynamically by the additional viscous resistance to upward flow caused by the presence of old, thick 1ithosphere across the transform fault. This results in an enhanced vertical pressure gradient near the intersection that reduces the height to which the asthenosphere can rise, thus deepening the axial valley. This downward force is balanced by shear stresses on the walls of the conduit, including the truncating older plate, potentially causing uplift. The Sleep-Biehler mechanism may be evident in the uplift observed opposite both Kane RTI, but it does not readily explain why the uplift of older seafloor persists as a continuous Iidge only along the eastern limb of the KFZ. The latter appears to require some process for enhancing flow at the eastern RTI. Perhaps flow beneath the rift valley south of the $\mathrm{KFZ}$ is more vigorous than the ridge segment to the north. Alternatively, the southward motion 
the the African plate relative to the underlying asthenosphere in the hot spot reference frame (as envisioned by Schouten et al., 1985) may tend to dam asthenospheric flow against the KFZ, the leading edge of the African plate, resulting in preferential uplift at the eastern RTI and along the KFZ to the east. However, the pattern of threedimensional mantle flow at an RTI is poorly understood and it is not clear whether either of these mechanisms can explain either the pattern or amplitude of the observed uplift.

We conclude that no single mechanism provides a completely atisfactory explanation for the origin of the KFZ transverse ridge, although certain possiblities can clearly be eliminated (excess volcanism, differential subsidence across the fracture zone, largescale cerpentine diapirism). Some combination of mechanisms is possible; for example, both thermal reheating and viscodynamic forces may be important near RTI and changing plate motions may affect the pattern of thenospheric flow near the transform. In the case of the KFZ cransverse ridge, the most 1ikely mechanisms appear to be either compression across the fracture zone due to different spreading directions north and south of the $\mathrm{KFZ}$ or a combination of thermal and viscodynamic forces acting near RTI. The main drawback to the compression hypothesis is explaining why the older, presumably more rigld plate buckles to form the ridge. Reheating and viscodynamic uplift cannot easily explain why transverse ridges do not exist at both Kane RTI without some mechanism for enhancing these processes at the eastern RTI. More information, particularly on the threedimensional temperature structure, flow pattern and stress field at RII, is needed to evaluate these hypotheses and their importance in explaining the vertical tectonism at fracture zones. 


\section{CONCLUSIONS}

Based on our Sea Beam maps of the KFZ transverse ridge and a remalysis of available gravity and seismic refraction data we draw the following conclusions:

(1) The KFZ transverse ridge first appears on 10 my old lithosphere opposite the eastern intersection of the KFZ and the MAR. It borders the north wall of the $\mathrm{KFZ}$ valley for at least $130 \mathrm{~km}$ east of the MAR and cepresents a major anomaly in the depth-age relation.

(2) Morphologically, the KFZ transverse ridge appears to be an uplifted block of oceanic crust. The rift valley-parallel Ceretionary fabric of the crust north of the KFZ can be traced, pesentially undisrupted, across the ridge. In cross-section, the ridge has a flexural shape that can be modeled by the bending of an elastic plate $3-4 \mathrm{~km}$ thick.

(3) The KFZ transverse ridge is not locally compensated by an werthickened crust or anomalously low mantle densities. The ridge Is associated with a mass excess that must either be dynamically supported or regionally compensated by the strength of the surrounding 1ithosphere.

(4) Selsmically, a broad zone $20-30 \mathrm{~km}$ wide with an elevated Moho is required beneath the $\mathrm{KFZ}$. The thinnest, most anomalous crust occurs in a narrow zone beneath the fracture zone valley. This thin crust but with normal upper crustal velocities extends beneath the south facing wall of the transverse ridge. Crustal thicknesses beneath the remainder of the transverse ridge are only slightly less than normal and seismic velocities are similar to normal oceanic crust. 
(5) No single mechanism provides a completely satisfactory explanation for the formation of the $\mathrm{KFZ}$ ridge, although certain hypotheses can be eliminated (constructional volcanism, differential subsidence across the fracture zone, large-scale serpentine (apirism). Any acceptable model must also account for the apparent saymmetry and episodicity in transverse ridge formation. The most likely mechanisms appear to be a combination of thermal and viscodynamic forces acting near RTI and/or changing relative plate motions. 
Figure 1. Generalized tectonic map showing the location of the Kane Transform (thick solid line), the Mid-Atlantic Ridge (MAR) rift valley (double line) and the aseismic extension of the Kane fracture zone (KFZ) east and west of the ridge crest (dashed line). The Kane Transform presently offsets the MAR rift valley by $150 \mathrm{~km}$. Superimposed on this map is the track coverage obtained during the 1983 Sea Beam, gravity and magnetics survey (Detrick et al., 1985). The track lines numbered one through eight cross the KFZ and KFZ transverse ridge at right angles and coincide with the location of the eight bathymetry and gravity profiles shown in Figures $3 a$ and 6 . The filled circles and triangles mark the reclever positions for the refraction experiments EXP77 (Detrick and Purdy, 1980) and ExP81 (Cormier et al., 1984) respectively. 


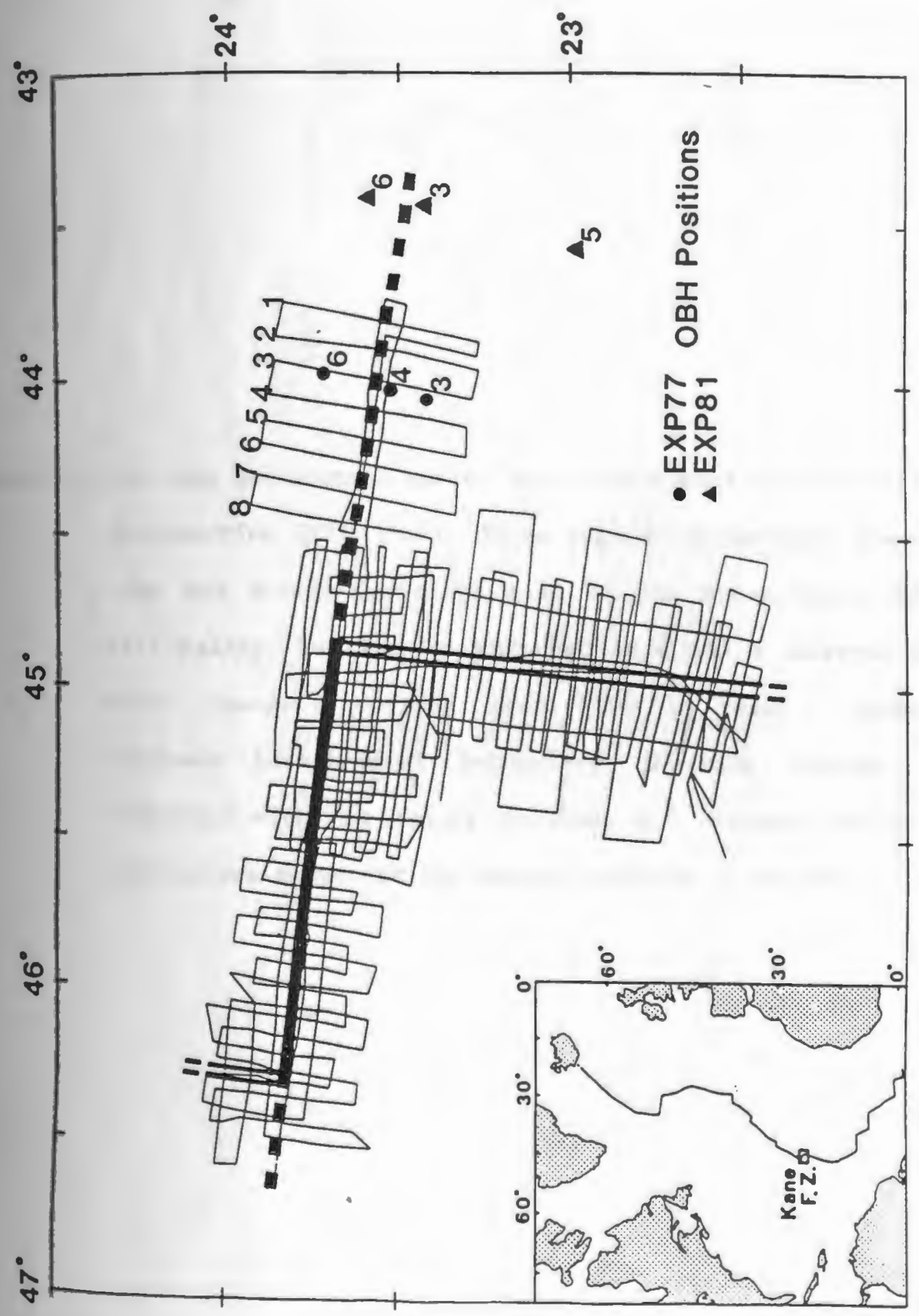


Figure 2. Sea Beam bathymetric map of the eastern Kane ridge-transform Intersection (RTI) and a $130 \mathrm{~km}$ segment of the Kane fracture zone and transverse ridge east of the Mid-Atlantic Ridge rift valley. The map is contoured at a $100 \mathrm{~m}$ interval with color changes occuring every $500 \mathrm{~m}$. Dashed contours indicate interpolated bathymetry. Shallow regions are indicated with hot colors (yellows and oranges) while the cold colors represent the deeper portions of the map. 


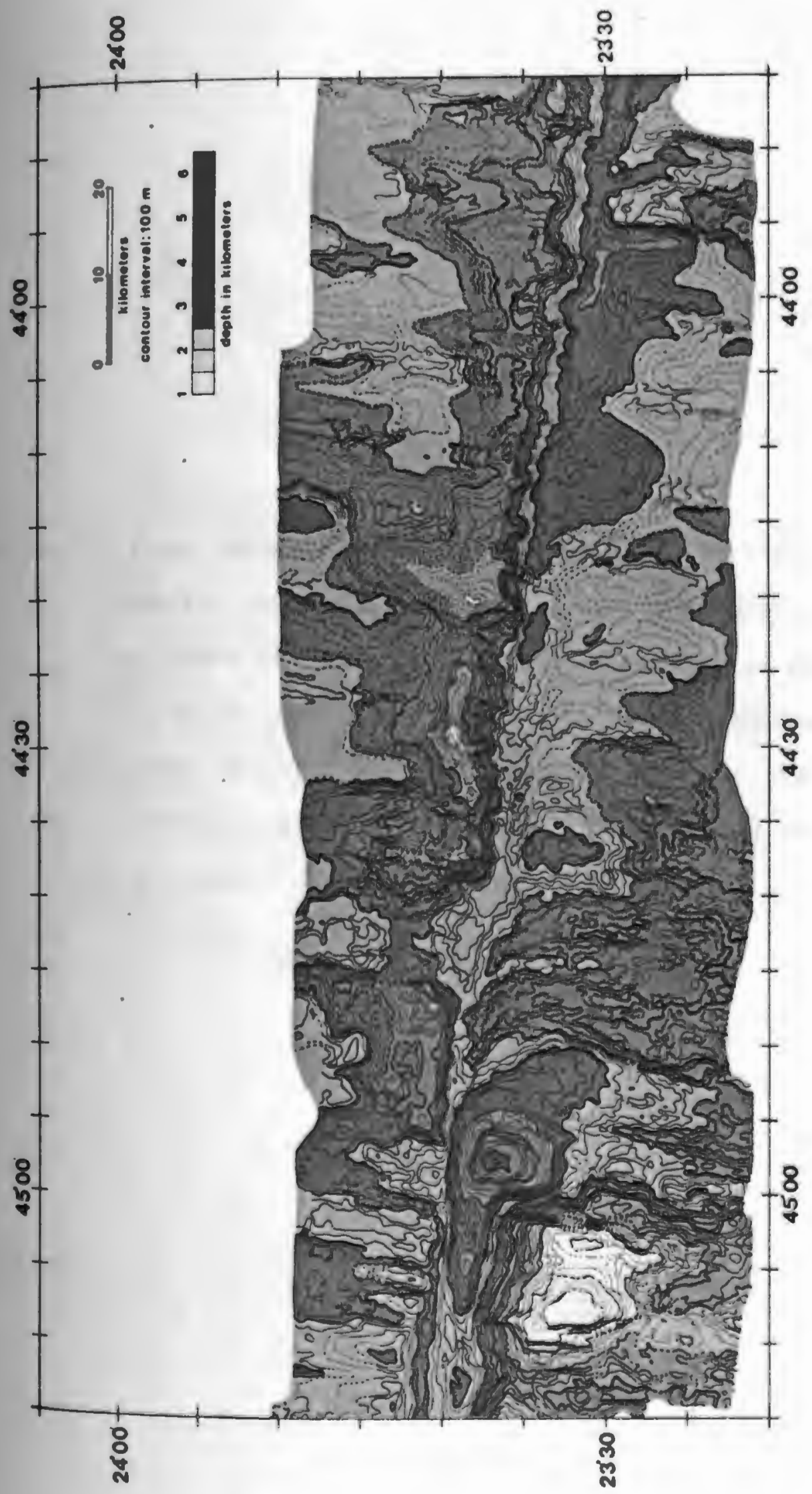


Figure 3a. Eight Sea Beam swath profiles across the Kane fracture zone and KFZ transverse ridge projected along $\mathrm{N} 10^{\circ} \mathrm{E}$ and located as shown in Figure 1. The view is from east to west looking along the KFZ trough (blues and purples) bordered to the north by the transverse ridge (orange and light green). Contour interval and color-coding is the same as in Figure 2 ; vertical exageration is $4: 1$. 


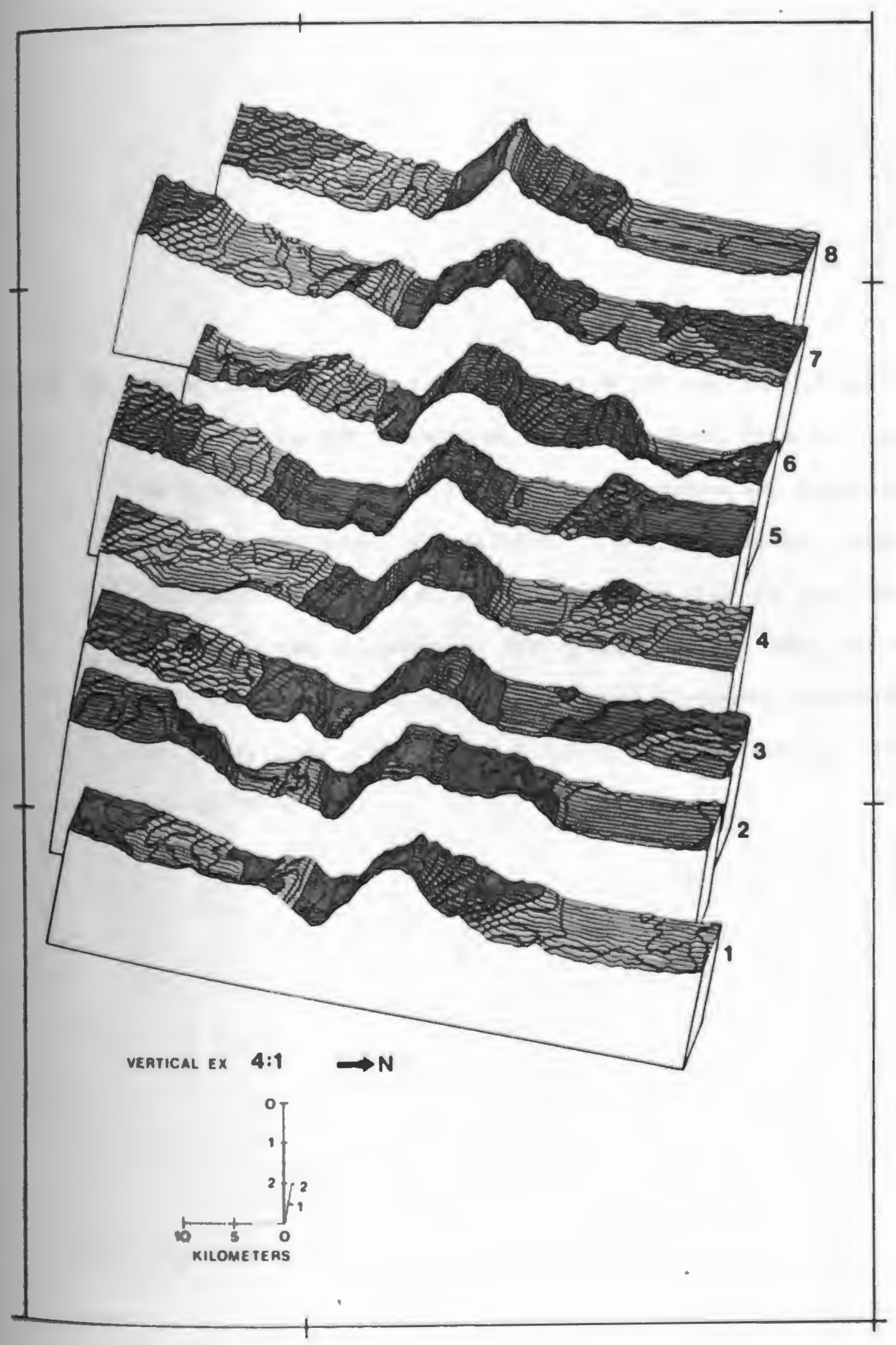


Figure 3b. Three dimensional perspective view of the Kane fracture zone and the KFZ transverse ridge, produced from Sea Beam bathymetry data gridded at a $250 \mathrm{~m}$ interval and displayed with a vertical exageration $4: 1$. The smooth areas represent interpolated bathymetry. The view is from east to west looking along the KFZ trough towards the eastern RTI. The rectangular area of seafloor displayed is bounded by longitudes $43^{\circ} 45^{\circ}$ and $45^{\circ} 00^{\prime} \mathrm{W}$ and latitudes $23^{\circ} 23^{\circ}$ and $230^{\circ} 50^{\prime} \mathrm{N}$. 


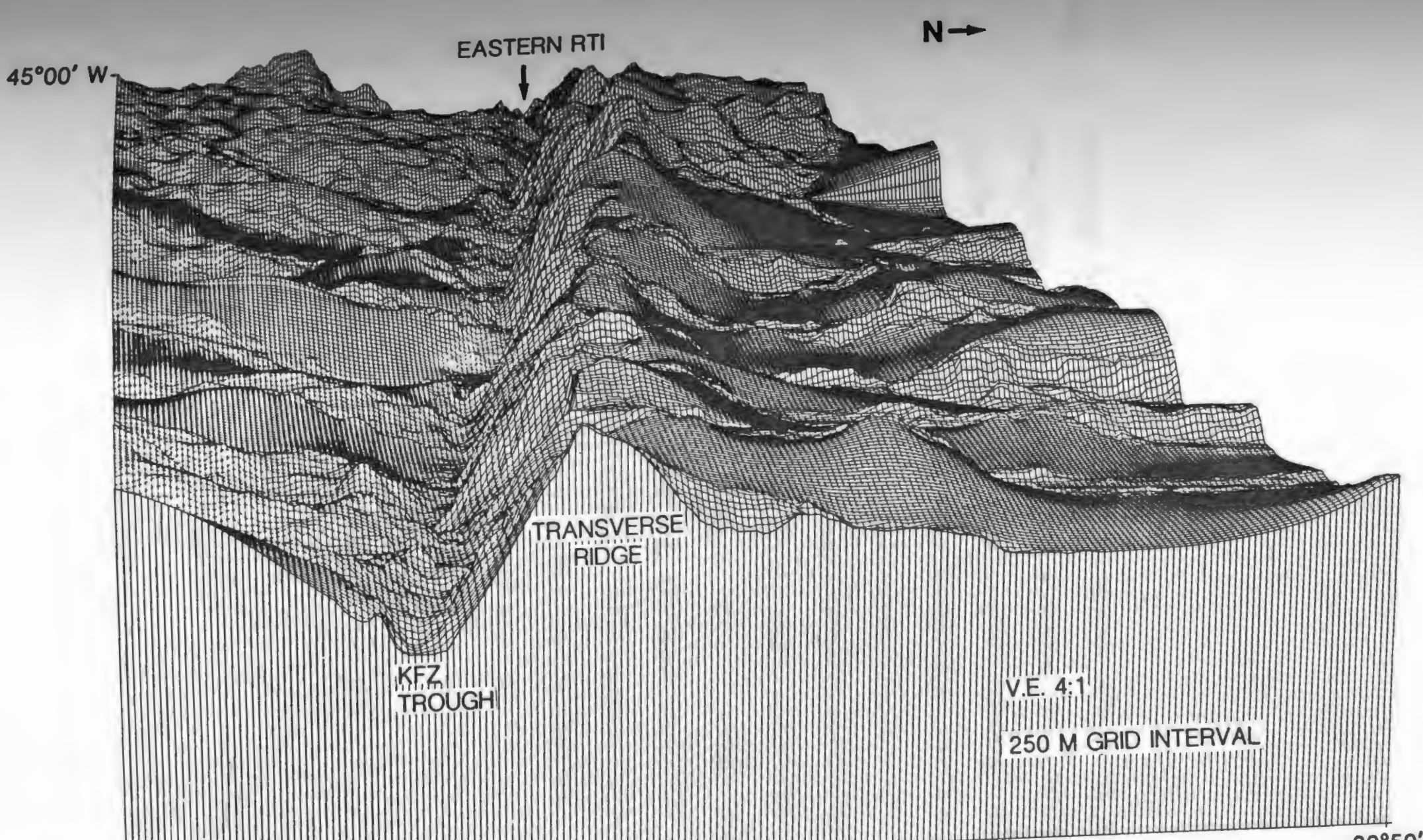

$43^{\circ} 45^{\prime}$ $23^{\circ} 23^{\prime} \mathrm{N}$ 
Figure 4. Averaged bathymetry profile (dotted line) across the transverse ridge produced by stacking the center beam depths of the eight Sea Beam swaths shown in Figure3a. Superimposed on this composite bathymetric profile are the calculated shapes of an elastic plate of varying thicknesses with a free edge at the fracture zone. The plate is loaded on its free end until the maximum deflection equals the height of the ridge above the predicted depth for crust of the same age ( $-17 \mathrm{~m} . \mathrm{y})$. A flexed elastic plate 3 to $4 \mathrm{~km}$ thick appears to best match the observed bathymetry. The corresponding flexural ridgidities are 24 to $57 \times 10^{18} \mathrm{~N}-\mathrm{M}$. 


\section{CALCULATED PLATE FLEXURE}

\section{OBSERVED BATHYMETRY}

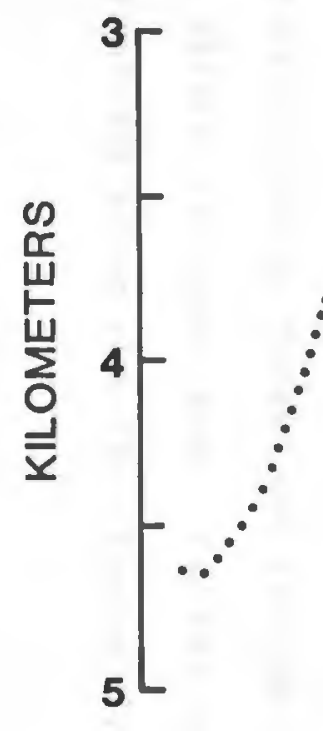

elastic plate thickness $\mathrm{kms}$

:

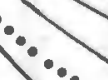
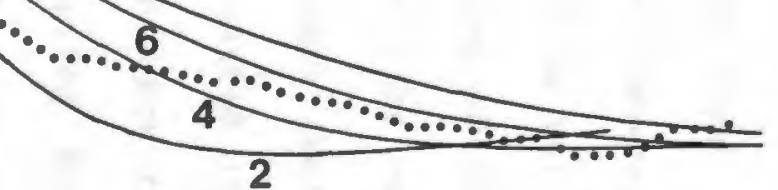

2

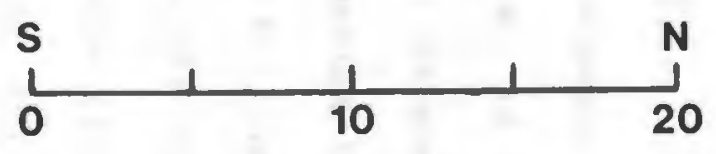

KILOMETERS 
Figure 5. Two depth vs. age profiles constructed from the Sea Beam bathymetry mapshown in Figure 2 and Pockalny et al., (1986) paralleling the Kane fracture zone. Profile B follows the axis of the transverse ridge while Profile $A$ is located approximatly $10 \mathrm{~km}$ north of Profile B. The insert indicates the orientation of the profiles with respect to the KFZ and the offset rift valley segments. Superimposed on the observed bathymetry (solid line) is the calculated depth vs. age curve (dotted line) of Parsons and Sclater (1977) . The arrows indicate the location of the eastern ridge-transform intersection. Near the RTI, bathymetry along Profile B rapidly shallows forming the KFZ transverse ridge (see text for discussion). The transverse ridge reaches its apex approximatly $40 \mathrm{~km}$ east of the RTI matching the location (but not the amplitude) of maximum thermal topography calculated by Morgan and Forsyth (1986) for a 10 m.y. age offset fracture zone. Further east the ridge appears to subside along with the adjacent 1ithosphere. 


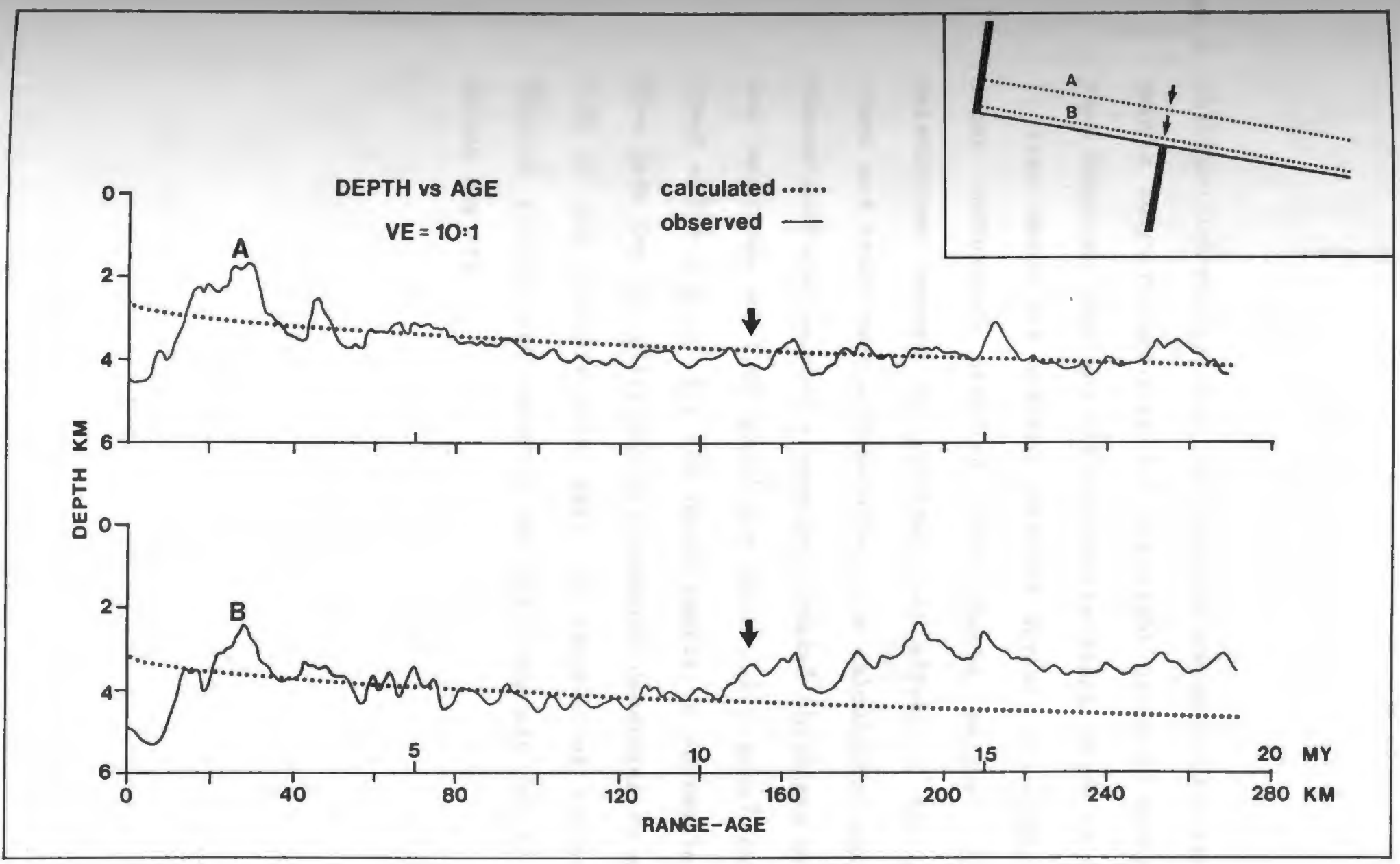


Tigure 6. Observed bathymetry, free air gravity anomaly and calculated mantle Bouguer anomalies for the eight profiles across the Kane fracture zone and KFZ transverse ridge shown in Figure 1. Also shown are stacked profiles derived by summing all eight individual profiles. The mantle Bouguer anomaly calculation removes the gravitational effect of the watercrust and crust-mantle boundaries. The calculation was twodimensional and assumed a constant crustal thickness of $5 \mathrm{~km}$ and densities of $1.03 \mathrm{~g} / \mathrm{cm}^{3}$ for water, $2.7 \mathrm{~g} / \mathrm{cm}^{3}$ for the crust and $3.3 \mathrm{~g} / \mathrm{cm}^{3}$ for the upper mantle. A correction was also made for the different 11thospheric densities on either side of the fracture zone using the method of Louden and Forsyth (1976) and assuming an age contrast of $10 \mathrm{~m} . \mathrm{y}$. across the $\mathrm{KFZ}$. 
Individual Proflles
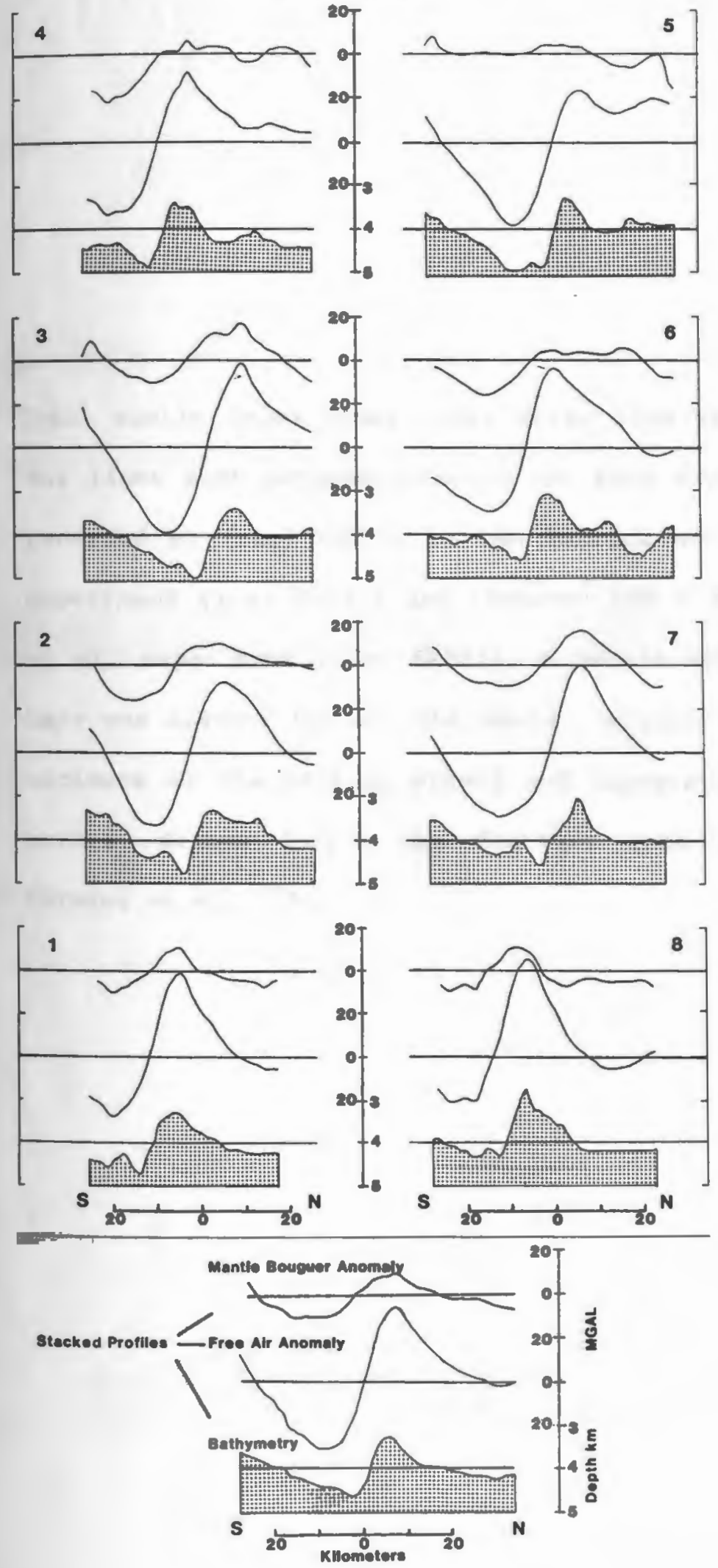
Figure 7. Total mantle delay times (shot delay plus reciever delay) for lines shot perpendicular to the Kane Fracture Zone as recorded by (top) OBH 5 in the Detrick and Purdy (1980) experiment (i.e. EXP77) and (bottom) OBH 8 in the Cormier et al. experiment (i.e. EXP81). A mantle velocity of 7.7 $\mathrm{km} / \mathrm{s}$ was assumed for all the shots. Vertical bars give the estimate of the picking errors and topographic correction errors. Arrows locate the fracture zone trough. (from Cormier et al. 1984). 

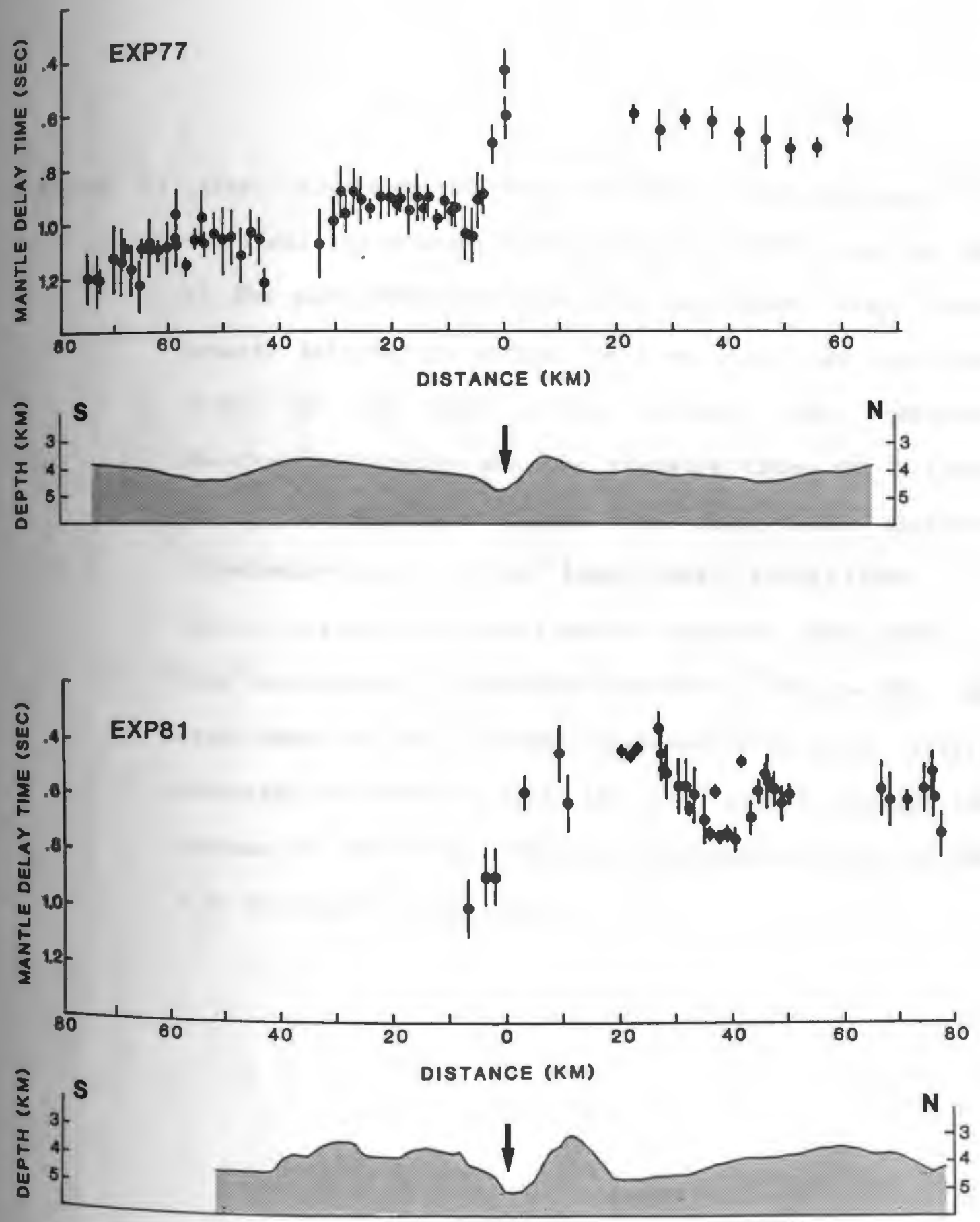
Pigure 8a. (Top) Calculated vs. observed travel times generated by the final ray tracing model along the EXP8I line for $O B H$ 5. The plot indicates that the calculated travel times (stars) fall mostly within the time error bars (vertical lines) of the first arrival travel times. (Middle) Observed bathymetry and the raypaths from OBH 5 (open arrow) constraining the final model along EXP81. (Bottom) Isovelocity plot of the final model along EXP81; 7.7 $\mathrm{km} / \mathrm{sec}$ is considered upper mantle velocity. This model is also constrained by raypaths from OBH 3 (Figure $8 b$ ). The crust south of OBH 5 is well represented by planar layers mirroring the seafloor (note the crust-mantle triplication between 20 and $30 \mathrm{~km}$ ). The crustal structure north of $O B H$ 5 is discussed in the text. 

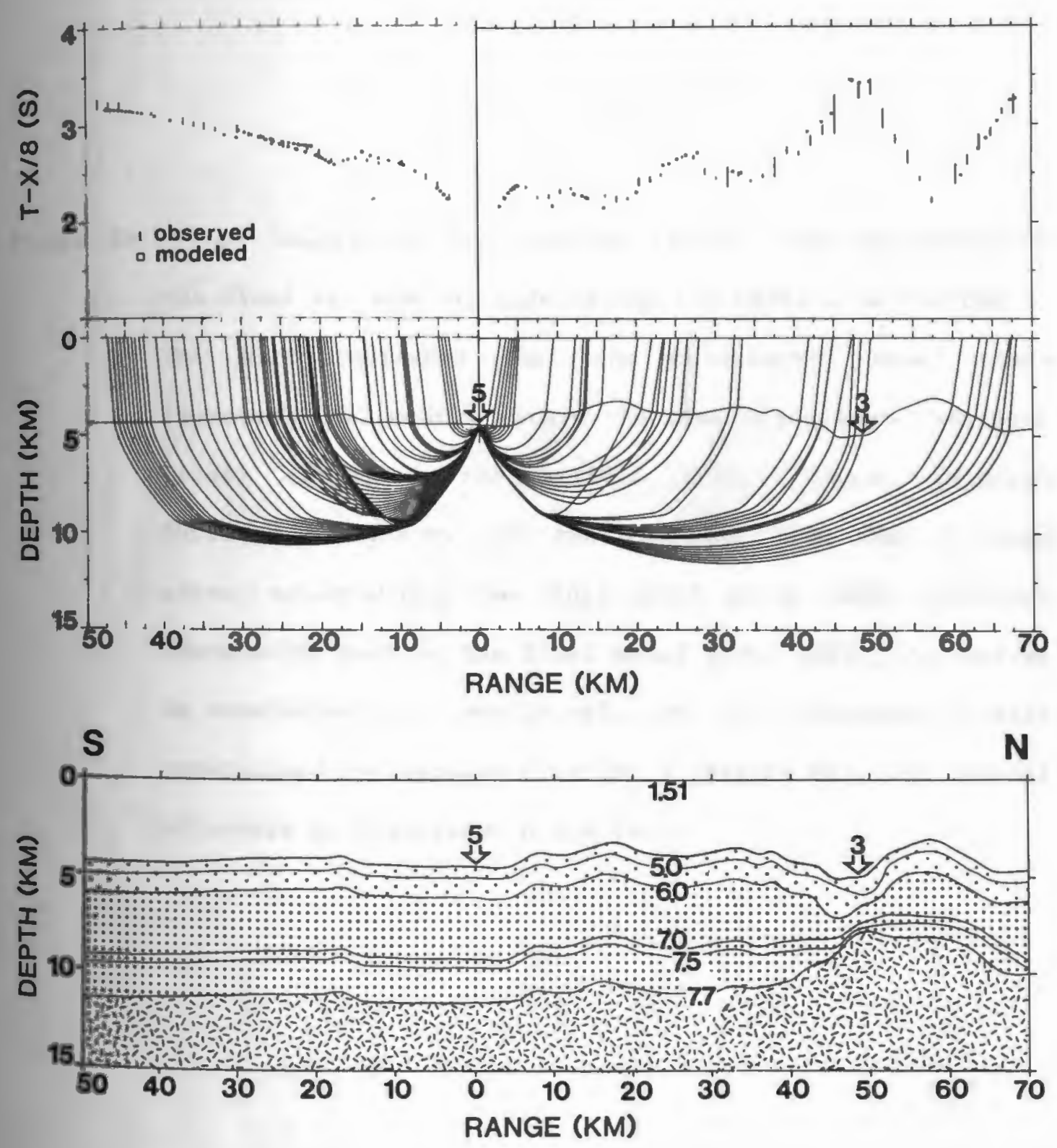
Figure 8b. (Top) Calculated vs. observed travel times generated by the final ray tracing model along the ExP81 line for OBH 3. The plot indicates that the calculated travel times (Squares) fall mostly within the time error bars (vertical lines) of the first arrival travel times. (Middle) Observed bathymetry and the raypaths from $\mathrm{OBH} 3$ (open arrow) constraining the final model along EXP81. (Bottom) Isovelocity plot of the final model along EXP81; $7.7 \mathrm{~km} / \mathrm{sec}$ is considered upper mantle velocity. This structure is also constrained by raypaths from OBH 5 (Figure 8a). The crustal structure is discussed in the text. 

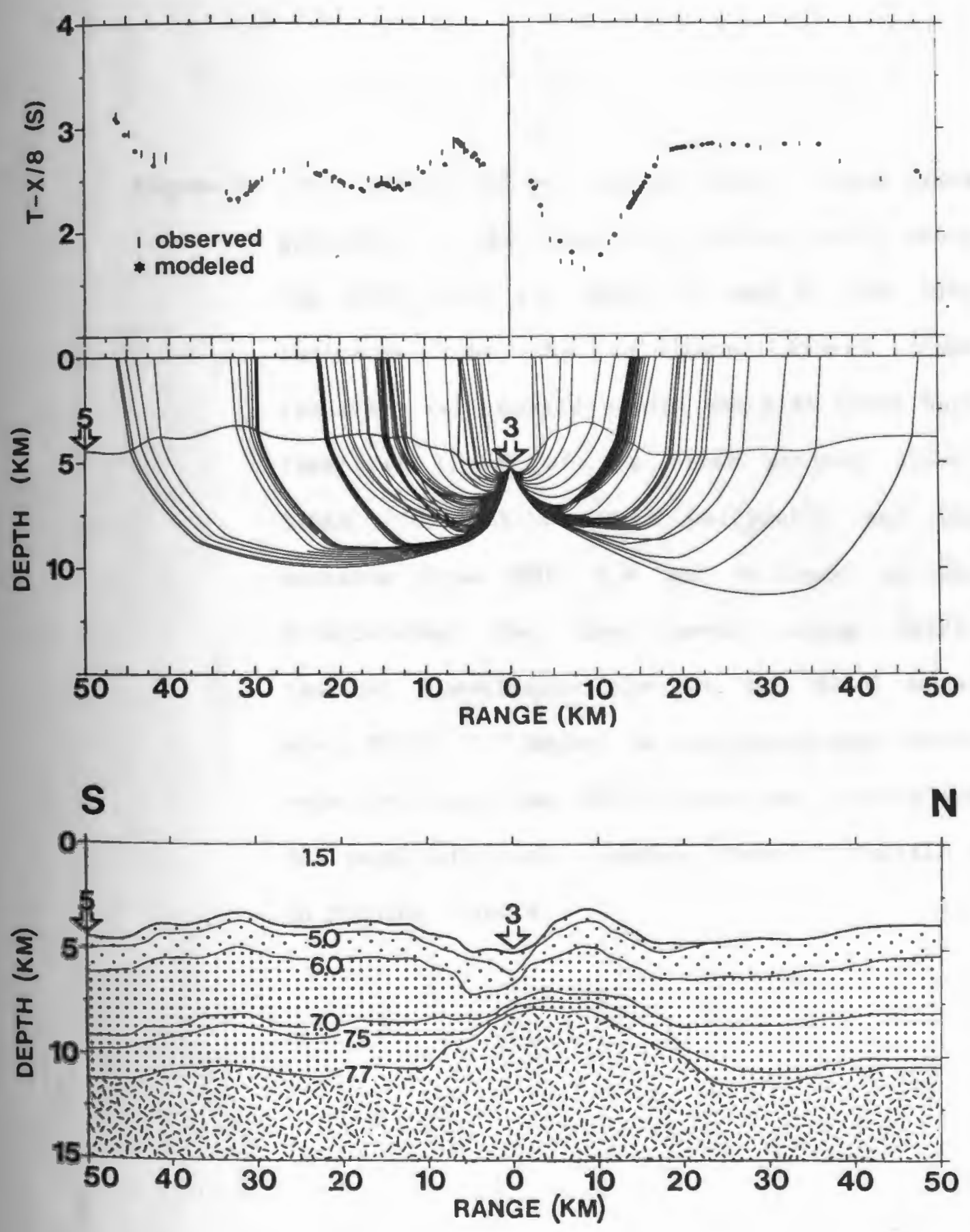
Figure 9. (Top) Calculated vs. observed travel times times generated by the final ray tracing model along the EXP77 line for OBHs 3,4 and 6 . The plot indicates that the calculated trave1 times (squares) fall mostly within the time error bars (vertical lines) of the first arrival trave1 times. (Middle) Observed bathymetry and the raypaths from OBHs 3,4 and 6 (open arrows) constraining the final model along EXP77. (Bottom) Isovelocity plot of the final model along EXP77; $7.7 \mathrm{~km} / \mathrm{sec}$ is considered upper mant1 velocity. This line (EXP77) also has gravity and Sea Beam bathymetry coverage shown in profile 3 In Figures 3 and 6. 

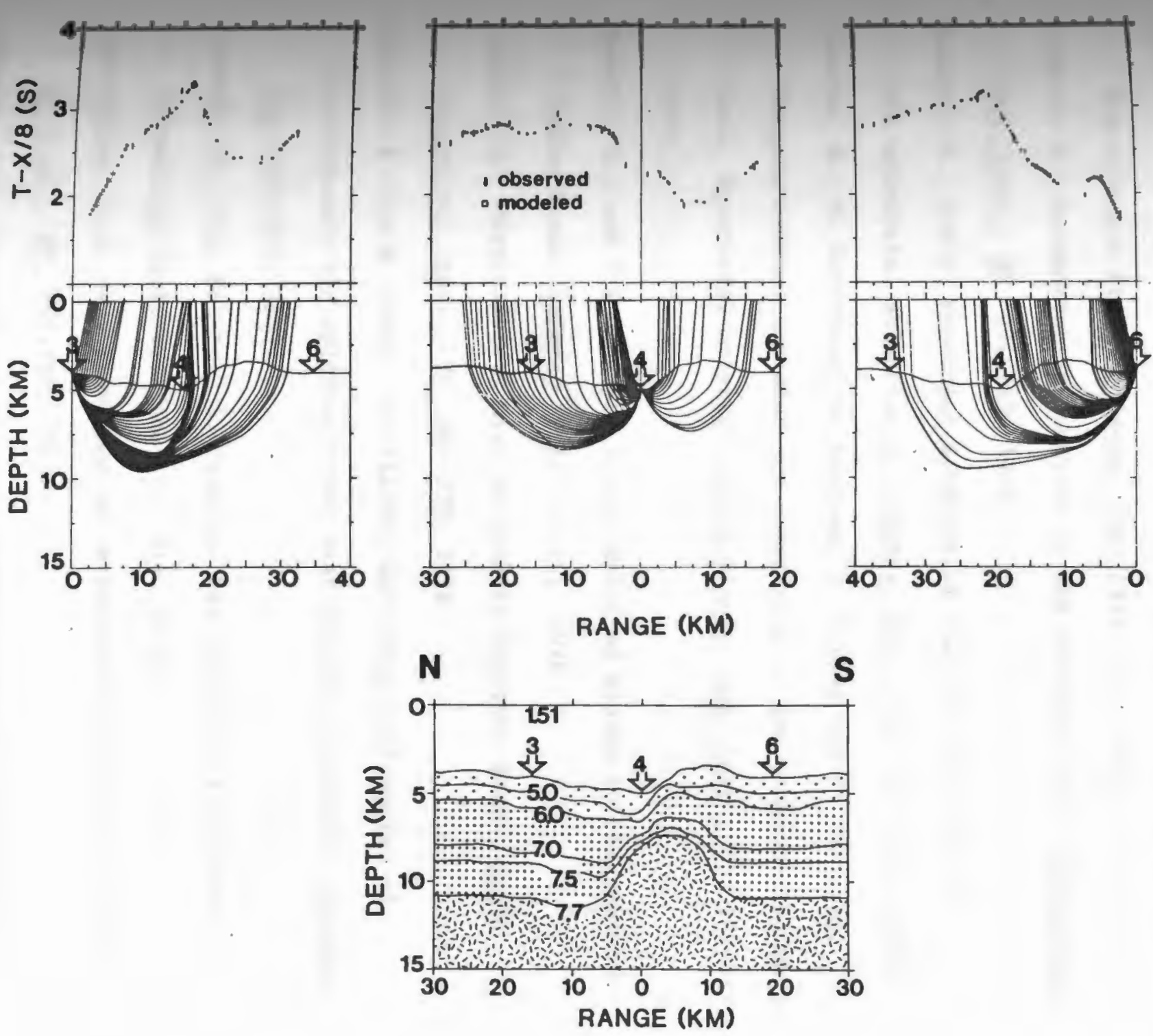


\section{REFERENCES}

tonatti, E., and J. Honnorez, Non-Spreading crustal blocks at the Aid-Atlantic Ridge, Science, 174, 1329-1331, 1971.

Bonatti, E., Serpentine protrusions in the oceanic crust, Earth Plant tei. Lett., 32, 107-113, 1976.

Bonatti, E., and J. Honnorez, Sections of the earth's crust in

the equatorial Atlantic, J. Geophys. Res., 81, 4104-4116, 1976.

Bonatti, E., M. Sarnthein, A. Boersma, M. Goring and J. Honnorez,

Neogene crustal emersion and subsidence at the Romanche Fracture

Zone, Equatorial Atlantic, Earth Planet. Sc1. Lett., 35, 369-383, 1977.

Bonatti, E., and P.R. Hamlyn, Mantle uplifted blocks in the western Indian Ocean, Science, 201, 249-251, 1978.

Bonatti, E., Vertical tectonism in oceanic fracture zones, Earth Met Sci. Lett., 37, 369-379, 1978.

Bonatti, E. and K. Crane, Oscillatory spreading explanation of anomalously old uplifted crust near oceanic transforms, Nature, 300, 343-345, 1982 .

Perveny, V., I.A. Molotov, I. Psencik, Ray method in seismology, Univerzita Karlova, Praha, pp. 214, 1977.

Christensen, N.I., The abundance of serpentinites in oceanic crust, Leo1., 80, 709-719, 1972 .

Gochran, J.R., Gravity and magnetic Investigations in the Guiana Basin, western equatorial Atlantic, Geol. Soc. Am. Bull., 84, $3249-3268,1973$. 
Dollette, B.J., A.P. Slootweg, J. Verhoef and W.R. Roest,

ceophysical investigations of the floor of the Atlantic Ocean

between $10^{\prime}$ and $38^{\prime} \mathrm{N}$ (Kroonvlag-project), Geophysics,

. Koninkiljke Nederlandse Akademie van Wetenschappen,

series C, 87,1984 .

collette,B.J., Fracture zones in th North Atlatic: morphology and a mode1, 1. Geo1. Soc. Lond., 143, 763-774, 1986.

Cormier M.H., R.S. Detrick and G.M. Purdy, Anomalously thin crust at oceanic fracture zones: New seismic constraints from the Kane fracture zone, J. Geophys. Res., 89, 10249-10266, 1984. Dohlinger, P., Marine Gravity, Elsevier, Amsterdam, pp 322, 1978. Detrick R.S. and G.M. Purdy, The crustal structure of the Kane fracture zone from seismic refraction studies, J. Geophys. Res., $\underline{85}, 3759-3777,1980$.

Detrick R.S., M.H. Cormier, R. Prince, and D.W. Forsyth, Seismic constraints on the crustal structure within the Vema Fracture Zone, ․ Geophys. Res., 87, 10,599-10,612, 1982.

Metrick R.S., P.J. Fox, K. Kastens, W.B.F. Ryan, L. Mayer and J.A. Karsen, A Seabeam survey of the Kane fracture zone and adjacent Mid-Atlantic Ridge rift valley, EOS, 65, 1006, (abstract), 1985. Fox P.J., W.C. Pitman III, and F. Shepard, Crustal Plates in the eentral Atlantic: Evidence for at least two poles of rotation, Acience, $165,487-489,1969$.

Fox, P.J., E. Schreiber, and J.J. Peterson, The geology of the oceanic crust: Compressional velocities of oceanic rocks, J. Ophys. Res., 78, 5155-5172, 1972. 
Fox, P.J., E. Schreiber, H. Rowlett and K. McCamy, The geology of the manographer Fracture Zone: a model for fracture zones, J. Bophys. Res., 81, 4117-4128, 1976.

Fox, P.J. and D.G. Ga110, A tectonic model for ridge-transform-ridge plate boundaries: Implications for the structure of oceanic 1ithosphere, Tectonophysics, 104, 205-242, 1984.

Fox, P.J. and D.G. Gallo, The geology of the North Atlantic Transform plate boundaries and their aseismic extensions, in The Geology of vamerica: The Western North Atlantic Region, edited by B.E. Tucholke, and P.R. Vogt, DNAG Series, Geol. Soc. Can., in press, 1986.

Francis, T.J.G., Serpentinization faults and their role in the tectonics of slow-spreading ridges, J. Geophys. Res., 86 , $11,616-11,622,1981$

Eorini, M., The tectonic fabric of the equatorial Atlantic and adjoining continental margins, Ph.D. Thesis, Columbia University, New York, N.Y., 1977.

Heezen, B.C. and M. Tharp, Tectonic fabric of the Atlantic and Indian Oceans, Philos. Trans. R. Soc. Lond., 258, 90-102, 1965.

Wonnorez, J., E. Bonatti, C. Emiliani, P. Bronnimann, M.A. Furrer and A.A. Meyeroff, Mesozoic limestones from the Vema offset zone, Alanet. Sci. Lett., 26, 8-12, 1975.

Rarson, J.A., and H.J.B. Dick, Tectonics of ridge-transform-ridge Intersections at the Kane Fracture Zone, Mar. Geophys. Res., $\underline{6}$, 51-98, 1983. 
3adsdale, P., Tectonic and magmatic ridges in the Eltanin fault

system, South Pacific, Mar. Geophys. Res., (in press), 1986.

Louden, K.E. and D.W. Forsyth, Thermal conduction across fracture zones and the gravitational edge effect, I. Geophys. Res.; 81 $4869-4874,1976$

Louden, K.E. and D.W. Forsyth, Crustal structure and isostatic

pompensation near the Kane fracture zone from topography

and gravity measurements - I. Spectral analysis approach,

Behys. J.R. Astron. Soc., 68, 725-750, 1982.

Louden, K.E., R.S. White, C.G. Potts, and D.W. Forsyth, Structure and seismotectonics of the Vema fracture zone, Atlantic Ocean, J. Pol. Soc. Lond., 143, 795-805, 1986.

Henard, H.W. and T.E. Chase, Fracture Zones, The Sea, 4-1, 421-443, Wley-Interscience, New York, 1970.

Minster, J.B., and T.M. Jordon, Present-day plate motions, J. Peophys. Res., 83, 5331-5354, 1978.

Morgan, J.P and D.W. Forsyth, 3-D flow and temperature perturbations due to a transform offset: Effects on oceanic crustal and upper mantle structure, J.Geol. Soc. Lond., Wm. Smith Vo1.,1986 (submitted).

Olivet, J.L., X. Le Pichon, S. Monti and B. Sichler, Charlie Gibbs Fracture Zone, J. Geophys. Res., 79, 2059-2072, 1974. OTTER, aceanographer Tectonic Research Team: J.A. Karson, P.J. Fox H. Sloan, K.T. Crane, W.S.F. Kidd, E. Bonatti, J.B. Stroup, D.J. Fornari, D. Elthon, P. Hamlyn, J.F. Casey, D.G. Gallo, D. Needham and R. Sartori, The Geology of the Oceanographer Transform; the ridge-transform intersection, Mar. Geophys. Res., 6, 109-141, 1984. 
OTTER, Deeanographer Tectonic Research Team: P.J. Fox, R. Moody, J.A. Rarson, K.T. Crane, W.S.F. Kidd, E. Bonatti, J.B. Stroup, D.J. Fornari, D. Elthon, P. Hamlyn, J.F. Casey, D.G. Gallo, D. Needham and R. Sartori, The Geology of the Oceanographer Transform; the ridge-transform intersection, Mar. Geophys. Res., 6, 329-358, 1985 .

Parsons, B., and J.G. Sclater, An analysisof the variation of ocean floor bathymetry and heat flow with age, J.Geophys. Res., 82 , $803-828,1977$.

Dockalny, R.A., R.S. Detrick and P.J. Fox, The morphology and tectonics of the Kane Transform from Sea Beam bathymetry data, J. Ceophys. Res. (Submitted), 1986.

Potts, C.G., R.S. White and K.E. Louden, Crustal structure of Atlantic fracture zones - II. The Vema fracture zone and transverse ridge, Tephys. J.R. astr. Soc., 86, 491-513, 1986.

Purdy, G.M., P.D. Rabinowitz and J.J.A. Velterop, The Kane Fracture Zone in the central Atlantic ocean, Earth Planet. Sci. Lett., 45, 429-434, 1979.

Purdy, G.M., and R.S. Detrick, Crustal structure of the Mid-Atlantic Ridge at $23^{\prime} \mathrm{N}$ from seismic refraction studies, J. Geophys. Res., 91, $3734-3762,1986$.

Mabinowitz, P.D., G.M. Purdy, The Kane fracture zone in the western central Atlantic ocean, Earth Planet. Sc1. Lett., 33, 21 $26,1976$. 
Robb, J.M., and M.F. Kane, Structure of the Vema Fracture Zone from Gravity and Magnetic Intensity profiles, J. Geophys. Res., 80, $4441-4445,1975$

Thdwe11, D.T., and G. Schubert, Lithospheric flexure at fracture zones, J. Geophys. Res., 87, 4657-4667, $1982 \mathrm{~b}$.

dondwe11, D.T., Thermomechanical evolution of oceanic fracture zones, J. Geophys. Res., 89, 11401-11413, 1984.

Schouten, H., K.D. Klitgord, and J.A. Whithead, Segmentation of mid ocean ridges, Nature, in press, 1986.

sibuet, J-C., and B. Veyrat-Peinet, Gravimetric model of the Atlantic quatorial fracture zones, J. Geophys. Res., 85, 943-954, 1980.

Sleep, N.H., and S. Biehler, Topography and tectonics at the Intersections of fracture zones and central rifts, J. Geophys. $\underline{\text { Res., }}$ 75, $2748-2752,1970$.

Tucholke, B.E., and H. Schouten, Global plate motion changes recorded in the Kane Fracture Zone, Geol. Soc. Am. Abstr. Programs, 17, no. 7,1985 .

Twight, W., J. Verhoef, K. Rohr, Th. F.A. Mulder, and B.J. Collette, lopography, magnetics and gravity over the Kane fracture zone in the Cretaceous Magnetic Quiet Zone (African Plate), Geophysics, Proceedings B $\underline{86}$ (2), 1983.

Van Andel, T.H., R.P. Von Herzen, and J.D. Phillips, The Vema Fracture Zone and the tectonics of transverse shear zones in oceanic crustal plates, Mar. Geophys. Res., 1, 261-283, 1971. Van Ande1, T.H., D.K. Rea, R.P. Von Herzen, and H. Hoskins, Ascension Fracture Zone; Ascension island and the Mid-Atlantic Ridge, Geol. …. Am. Bul1., 84, 825-840, 1973. 
White, R.S., R.S. Detrick, M.C. Sinha and M.H. Cormier, Anomalous seismic crustal structure of oceanic fracture zones, Geophys. H. R. astr. Soc., 79, 779-798, 1984.

Whitmarsh, R.B., and A.J. Calvert, Crustal structure of Atlantic fracture zones: I - The Charlie Gibbs FZ, Geophys. J. Roy. Astro. Soc., 85, 107-138, 1986. 
TPENDIX A: Ray tracing models

\section{Construction}

The single largest source for error in the interpretation of arine seismic data is topographic corrections. These corrections assume a structure comprised of a stack laterally homogenous layers either planar or mirroring the seafloor and require the variation in Wthymetry not to exeed $500 \mathrm{~m}$ (Purdy, 1982). Although this represents a gross simplification of the actual geologic structure, it generally provides satisfactory results. However, there are instances when the geology is known to be complex, the bathymetry rugged and where such Tmplifying assumptions cannot be made without introducing large errors. One method of investigating such areas using seismic wraction data is through seismic ray tracing. The ray tracing program of Cerveny et al. (1977) is capable of modeling travel times for rays traveling through a heterogenous two-dimensional velocity structure and includes the observed bathymetry thus avoiding any pographic corrections.

The ray tracing models presented in the manuscript and this eppendix were created by specifying velocities within a range vs. depth matrix. The matrix is formed by specifying the range (horizontal axis) of up to 30 vertical "mesh" lines from the ocean bottom hydrophone (OBH) position. Depths (vertical axis) along each mesh line are specified, an interface is then created by a cubic spline fit through these depth vs range points. The seafloor, for example, is termined by a cubic spline fit to depth vs range data from Sea Beam 
or $3.5 \mathrm{KHZ}$ echo sounder data. The depths to subsequent interfaces are based on assumed or any available velocity/depth information. A wocity is specified above and below each interface where they Grersect the vertical mesh lines. Velocities between these intersection points are determined by linear interpolation. Seismic energy is then traced as ray paths "shot" from the OBH to the sea vurface using Runge-Kutta integration techniques to solve the system of partial differential equations that represent the wave equation. Ray paths are determined by specifying the initial angle of incidence for each ray. The travel times calculated for a suite of ray paths are eapared with the first arrival times picked from original record actions until a match is achieved.

\section{Ing Models not Presented in the Manuscript}

The $100 \mathrm{~km}$ EXP81 transverse profile from OBH 5 to $50 \mathrm{~km}$ north of the KFZ was first modeled to OBH 5 using a constant thickness crust $(6.25 \mathrm{~km})$ with layers parallel to bathymetry denoting the velocity/depth structure derived by Cormier et al. (1984) for OBH 5. The travel time match for arrivals south of OBH 5 using this structure is almost exact (Figure $8 \mathrm{a}$ in manuscript). However, within $10 \mathrm{~km}$ south of the $\mathrm{KFZ}$ and northward the modeled arrivals are all too late and the interfaces mirroring the extreme bathymetry do not allow many geometrical diving ray arrivals (Figure Al).

The same structure was used to model travel times for $O B H 3$ (Figure A2). The modeled arrivals south of $\mathrm{OBH} 3$ are clearly much too arly $(.25 \mathrm{sec})$ where as north of OBH 3 calculated and observed travel 
times match we11 within $15 \mathrm{~km}$ range but further north modeled travel times are significantly late. The mismatches of travel times for both OBH 5 and $\mathrm{OBH} 3$ immediately discredit a uniform "normal" crustal structure beneath the $\mathrm{KFZ}$ and transverse ridge, and the direction of Asmatch provides the initial clues toward a better model. Modeled arrival times for ray paths traveling under the $\mathrm{KFZ}$ and through the cransverse ridge to both $\mathrm{OBH} 3$ and 5 are all late, necessitating a structure with higher velocities at some depth beneath the $\mathrm{KFZ}$ and transverse ridge. Possible structures include higher velocities within a normal thickness crust or thinner crust (raised isovelocity contours) with a lower average velocity, the combinations of various velocities and thicknesses are many. The well constrained velocity/depth data from Cormier et al. (1984) along the KFZ trough Wicates thin $(2.6 \mathrm{~km})$, low velocity (begining at $2.6 \mathrm{~km} / \mathrm{s}$ ) crust with high velocity gradients $(2 / s)$ terminated with a sharp moho boundary. In addition, velocity/depth constraints indicate normal 6.6 $\mathrm{km}$ thick oceanic crust $20 \mathrm{~km}$ north of the $\mathrm{KFZ}$. This information ponsiderably narrows the number of different velocity/depth structures possible across the $\mathrm{KFZ}$ and transverse ridge. Thus, modeling proceeded theping $\mathrm{OBH} 5,3$ and 6 and bathymetry as constants while only varying the structure between $O B H$ positions. The final models are presented in ligures 8 and 9 of the manuscript. 
Figure Al. (Top) Calculated vs observed travel times generated by a "normal", constant thickness $(6.25 \mathrm{~km})$ crustal model for OBH 5 (EXP81). The plot indicates that the calculated travel times (squares) do not fall within the time error bars (vertical lines) of most of the first arrival travel times within $10 \mathrm{~km}$ of the $\mathrm{KFZ}$. (Middle) Observed bathymetry and the ray paths from OBH 5 (open) arrow) constraining this model along EXP81. (Bottom) Isovelocity plot of a "normal" constant thickness crustal model (velocity in $\mathrm{km} / \mathrm{s}$ ). This model is also constrained by ray paths from $\mathrm{OBH} 3$ (Figure $\mathrm{A} 2$ ). 

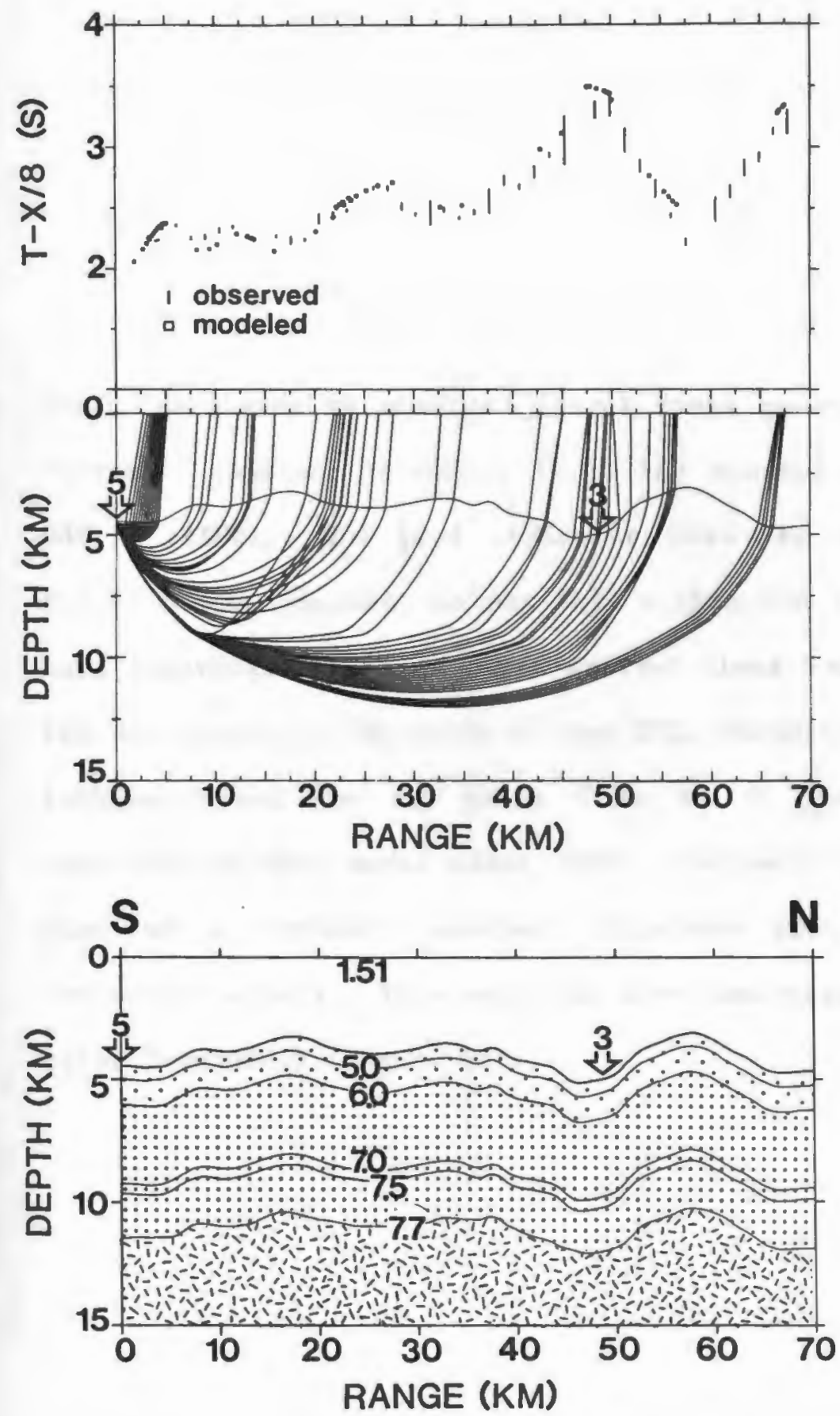
Figure A2. (Top) Calculated vs observed travel times generated by a "normal", constant thickness $(6.25 \mathrm{~km})$ crustal model for $\mathrm{OBH} 3$ (EXP81). The plot indicates that the calculated travel times (squares) do not fall within the time error bars (vertical lines) of first arrival times south of the $\mathrm{KFZ}$ and beyond $15 \mathrm{~km}$ north of the KFZ. (Middle) Observed bathymetry and the ray paths from $\mathrm{OBH} 3$ (open arrow) constraining this model along EXP81. (Bottom) Isovelocity plot of a "normal" constant thickness crustal model (velocity in $\mathrm{km} / \mathrm{s}$ ). This model is also constrained by ray paths from OBH 5 (Figure Al). 

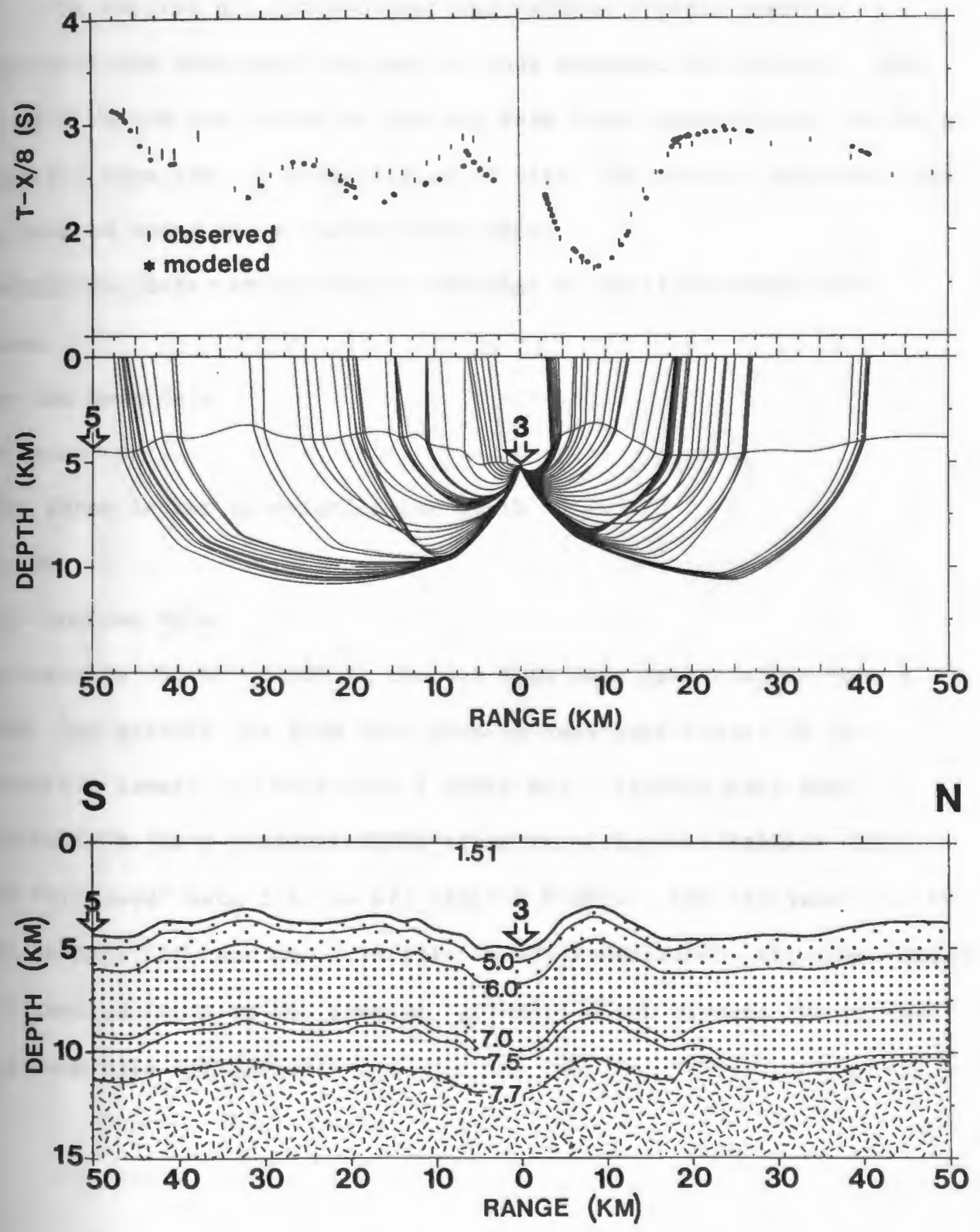
PENDIX B: Data Storage

The shifted and gridded Sea Beam bathymetry data used to construct the bathymetry map and various bathymetric displays found In this thesis are stored at the Sea Beam Development Center at URI on Dagnetic tape and are presently up on disk. The shifted bathymetry is is located under the following path name;

[DATA\$DISK: [ DATA.SEABEAM.RC2511. PPROCESS .NAVSHIFT] CBYYMMMDD .SOO ]

where:

$\mathrm{CB}-$ Sea Beam data

YY- year

MMM = three letter abreviation for month

$\mathrm{DD}=$ day

SOO= shifted data

for example CB84NOV08.S00 is the Sea Beam data collected on Nov. 8 , 1984. The gridded Sea Beam data used to construct Figure $3 \mathrm{~b}$ is presently located on Micro Vax 1 under the following path name; [SPARE\$DISK: [DATA.REGIONAL.NORTH_ATLANTIC.MARK.GRIDS] FAREAST.GRID] The "windowed" data file is RTI_FAREAST.WINDOWS, the "include file is RTI_FAREAST.LIS, and the card file is RTI_FAREAST.CRD. All three files are used as input to the program "gridder" which creates the gridded Sea Beam file FAREAST.GRID. 


\section{BIBLIOGRAPHY}

Bonatti, E., and J. Honnorez, Non - Spreading crustal blocks at the Md-Atlantic Ridge, Science, 174, 1329-1331, 1971.

Bonatti, E., Serpentine protrusions in the oceanic crust, Earth Plant Bei. Lett., 32, 107-113, 1976.

Bonatti, E., and J. Honnorez, Sections of the earth's crust in

the equatorial Atlantic, J. Geophys. Res., 81, 4104-4116, 1976.

Bonatti, E., M. Sarnthein, A. Boersma, M. Goring and J. Honnorez,

Neogene crustal emersion and subsidence at the Romanche Fracture Zone, Equatorial Atlantic, Earth Planet. Sci. Lett., 35, 369-383, 1977.

Bonatti, E., and P.R. Hamlyn, Mantle uplifted blocks in the western Indian Ocean, Science, 201, 249-251, 1978.

Bonatti, E., Vertical tectonism in oceanic fracture zones, Earth Planet Sci. Lett., 37, 369-379, 1978.

Bonatti, E. and A. Chermak, Formerly emerging crustal blocks in the equitorial Atlantic, Tectonophysics, 22, 165-180, 1981. Bonatti, E. and K. Crane, Oscillatory spreading explanation of anomalously old crust near oceanic transforms, Nature, $\underline{300}, 343$ 345,1982

Bonatti, E., R. Satori, and A. Boersma, Vertical crustal movements at the Vema Fracture Zone in the Atlantic: Evidence from dredged 1imestones, Tectonophysics, 91, 213-232, 1983.

Bryan, W.B., C. Thompson, and J.N. Ludden, Compositional variation in normal MORB from 22'-25'N: Mid-Atlantic Ridge and Kane Fracture Zone, J. Geophys. Res., 86, 11815-11836, 1981. 
Calvert, A.J. and C.G. Potts, Seismic evidence for hydrothermaly

altered upper mantle beneath old crust in the Tydeman Fracture Zone, Earth Planet. Sci. Lett., 75, 439-449, 1985.

Carlson, R.L. and G.S. Raskin, Density of the ocean crust, Nature, 311, $555-558,1984$.

Cerveny, V., I.A. Molotov, I. Psencik, Ray method in seismology, Univerzita Karlova, Praha, pp. 214, 1977.

Christensen, N.I. and M.H. Salisbury, Structure and constitution of the lower oceanic crust, Rev. Geophys. Space Physics, 13, 1975.

Cochran, J.R., Gravity and magnetic investigations in the Guiana Basin, western equatorial Atlantic, Geol. Soc. Am. Bull., 84, $3249-3268,1973$.

Gollette, B.J., Thermal contraction joints in a spreading seafloor as origin of fracture zones, Nature, 251, 299-300, 1974. Wollette, B.J., A.P. Slootweg, J. Verhoef and W.R. Roest, Geophysical investigations of the floor of the Atlantic Ocean between $10^{\prime}$ and $38^{\prime} \mathrm{N}$ (Kroonvlag-project), Geophysics,

Eroc. Koninkiljke Nederlandse Akademie van Wetenschappen, series $C, \underline{87}, 1984$.

Pollette,B.J., Fracture zones in the North Atlatic: morphology and a mode1, J. Geo1. Soc. Lond., 143, 763-774, 1986.

Cormier M.H., R.S. Detrick and G.M. Purdy, Anomalously thin crust at oceanic fracture zones: New seismic constraints from the Kane fracture zone, J. Geophys. Res., 89, 10249-10266, 1984. hlinger, P., Marine Gravity, Elsevier, Amsterdam, pp 322, 1978. 
Detrick R.S. and G.M. Purdy, The crustal structure of the Kane

fracture zone from seismic refraction studies, J. Geophys. Res., 85, 3759-3777, 1980 .

Detrick R.S., M.H. Cormier, R. Prince, and D.W. Forsyth, Seismic constraints on the crustal structure within the Vema Fracture Zone, J. Geophys.Res., 87, 10,599-10,612, 1982.

Detrick R.S., P.J. Fox, K. Kastens, W.B.F. Ryan, L. Mayer and J.A. Karsen, A Seabeam survey of the Kane fracture zone and adjacent Mid-Atlantic Ridge rift valley, EOS, 65, 1006, (abstract), 1984. Fox P.J., W.C. Pitman III, and F. Shepard, Crustal Plates in the Central Atlantic: Evidence for at least two poles of rotation, Science, 165, 487-489, 1969.

Fox, P.J., E. Schreiber, and J.J. Peterson, The geology of the oceanic crust: Compressional velocities of oceanic rocks, J. Geophys. Res., 78, 5155-5172, 1972.

Fox, P.J., E. Schreiber, H. Rowlett and K. McCamy, The geology of the Dceanographer Fracture Zone: a model for fracture zones, J. Geophys. Res., 81, 4117-4128, 1976.

Fox, P.J. and D.G. Gallo, A tectonic model for ridge-transform-ridge plate boundaries: Implications for the structure of oceanic 1ithosphere, Tectonophysics, 104, 205-242, 1984.

Fox, P.J. and D.G. Gallo, The geology of the North Atlantic Transform plate boundaries and their aseismic extensions, in The Geology of North America: The Western North Atlantic Region, edited by B.E. Tucholke, and P.R. Vogt, DNAG Series, Geol. Soc. Can., in press, 1986. 
Wrancis, T.J.G., Serpentinisation faults and their role in the

tectonics of slow-spreading ridges, J. Geophys. Res., $\underline{86}, 11,616$ $11,622,1986$.

Ga11o, D.G., P.J. Fox, and K.C. Macdonald, A Sea Beam Investigation of the Clipperton Transform Fault: The morphotectonic expression of a fast slipping transform boundary, J. Geophys. Res., 91, 3455$3467,1986$.

Gorini, M., The tectonic fabric of the equatorial Atlantic and adjoining continental margins, Ph.D. Thesis, Columbia University, Ney York, N.Y., 1977.

Heezen, B.C. and M. Tharp, Tectonic fabric of the Atlantic and Indian Oceans, Philos. Trans. R. Soc. Lond., 258, 90-102, 1965.

Honnorez, J., E. Bonatti, C. Emiliani, P. Bronnimann, M.A. Furrer and A.A. Meyeroff, Mesozolc limestones from the Vema offset zone, Earth Planet. Sci. Lett., 26, 8-12, 1975.

Honnorez, J., R.S. Detrick, A. Adamson, G. Brass, K. Gillis, S. Humphris, C. Mevel, P. Meyer, N. Peterson, M. Rautenschlein, T. Shibata, H. Staudigal, A. Woolridge, and K. Yamamoto, Drilling in the Snake-Pit hydrothermal area in the Mid-Atlantic Ridge rift valley south of the Kane Fracture Zone: Highlights from ODP Leg 106, EOS Trans. AGU, 67, 365, 1986.

Karson, J.A., and H.J.B. Dick, Tectonics of ridge-transform-ridge Intersections at the Kane Fracture Zone, Mar. Geophys. Res., $\underline{6}$, $51-98,1983$. 
Karson, J.A., Variations in structures and petrology in the coastal complex, Newfoundland: an anatomy of a fracture zone, J. Geol. Soc. London, 1984.

Nachenbruch, A.H., A simple mechanical model for oceanic spreading centers, J. Geophys. Res., 78, 3395-3417, 1973.

Langmuir, C.H. and J.F. Bender, The geochemistry of oceanic basalts in the vicinity of transform faults: observations and implications, Earth Planet. Sci. Lett., 69, 107-127, 1984. Londsdale, P., Tectonic and magmatic ridges in the Eltanin fault system, South Pacific, Mar. Geophys. Res., (in press), 1986. Louden, K.E. and D.W. Forsyth, Thermal conduction across fracture zones and the gravitational edge effect, J. Geophys. Res., 81 $4869-4874,1976$.

Louden, K.E. and D.W. Forsyth, Crustal structure and isostatic compensation near the Kane fracture zone from topography and gravity measurements - I. Spectral analysis approach, Geophys. J.R. Astron. Soc., 68, 725-750, 1982.

Louden, K.E., R.S. White, C.G. Potts, and D.W. Forsyth, Structure and seismotectonics of the Vema fracture zone, Atlantic Ocean, $\mathrm{J}$. Geo1. Soc. Lond., 143, 795-805, 1986.

Ludwig, W.J. and P.D. Rabinowitz, Structure of the Vema Fracture Zone, Mar. Geo1., 35, 99-110, 1980.

Hacdonald, K.C., J.C. D. Castillo, S. Miller, P.J. Fox, K. Kastens, and E. Bonatti, Deep-tow studies of the Vema Fracture Zone: 1The tectonics of a major sloe-slipping transform fault and its intersection with the Mid-Atlantic Ridge, J. Geophys. Res., 91, $3334-3354,1986$. 
Machado, N., J. Ludden, and C. Brooks, The Isotropic chartacter of the Atlantic ocean mantle at $23^{\prime} \mathrm{N}$, AGU Chapmand Conf. (absract), 1981.

Madsen, J.A., D.W. Forsyth, R.S. Detrick, A new isostatic model for the East Pacific Rise crest, J. Geophys. Res., 89, $9997-10015,1984$.

Mckenzie, D.P. and J.G. Sclater, Heat flow in the eastern Pacific and sea-floor spreading, Bull. Volcanol., 33, 101-118, 1969. McClain, J.S., J.A. Orcutt, and M. Burnett, The East Pacific Rise in cross section: A seismic model, J. Geophys. Res., 90, 8627-8640, 1985.

Melson, W.G. and G. Thompson, Petrology of a transform zone and adjacent ridge segments, Philos. Trans. R. Soc. Lond., 268, $423-441,1971$.

Menard, H.W. and T. Atwater, Changes in direction of sea floor spreading, Nature, $\underline{219}, 463-467,1968$.

Menard, H.W. and T. Atwater, Origin of fracture zone topography, Nature, 222, 1037-1041, 1969.

Menard, H.W., Elevation and subsidence of the oceanic crust, Earth Planet. Sci. Lett., 6, 275-284, 1969.

Menard, H.W. and T.E. Chase, Fracture Zones, The Sea, 4-1, 421-443, Wiley-Interscience, New York, 1970.

Minster, J.B., and T.M. Jordon, Present-day plate motions, J. Geophys. Res., 83, 5331-5354, 1978.

Miyashiro, A., F. Shido, and M. Ewing, Composition and origin of serpentinites from the Mid-Atlantic Ridge, $24^{\prime}$ and $30^{\prime} \mathrm{N}$, Contrib. Mineral. Petrol., 32, 38-52, 1969. 
Morgan, J.P and D.W. Forsyth, 3-D flow and temperature perturbations due to a transform offset: Effects on oceanic crustal and upper mantle structure, J. Geol. Soc. Lond., Wm. Smith Vol.,1986 (submitted).

Mutter, J.C., Detrick, R.S., North Atlantic Transect Study Group, Multichannel seismic evidence for anomalously thin crust at Blake Spur fracture zone, Geology, 12, 534-537.

NAT, North Atlantic Study Group: A wide-aperature, two-ship multichannel seismic investigation of the oceanic crust, $\mathrm{J}$. Geophys. Res., 90, 10,321-10,341, 1985.

Nicolas, A., and J.F. Violette, Mantle flow at oceanic spreading centers: models derived from ophiolites, Tectonophysics, 81, 319 339,1982

Olivet, J.L., X. Le Pichon, S. Monti and B. Sichler, Charlie Gibbs Fracture Zone, J. Geophys. Res., 79, 2059-2072, 1974.

Otter, Oceanographer Tectonic Research Team: J.A. Karson, P.J. Fox, H. Sloan, K.T. Crane, W.S.F. Kidd, E. Bonatti, J.B. Stroup, D.J. Fornari, D. Elthon, P. Hamlyn, J. F. Casey, D.G. Gallo, D. Needham, and R. Sartori, The Geology of the Oceanographer Transform; the ridge-transform intersection, Mar. Geophys. Res., 6, $109-141,1984$.

Otter, Oceanographer Tectonic Research Team: P.J. Fox, R. Moody, J.A. Karson, K.T. Crane, W.S.F. Kidd, E. Bonatti, J.B. Stroup, D.J. Fornari, D. Elthon, P. Hamlyn, J. F. Casey, D.G. Gallo, D. Needham, and R. Sartori, The Geology of the Oceanographer Transform; the transform domain, Mar. Geophys. Res., ㄱ, 329-358, 1985. 
Parker, R.L., The rapid calculation of potential anomalies, Geophys. J. R. Astr. Soc., 31, 447-455, 1972 .

Parker, R.L., and D.W. Oldenburg, Thermal model of ocean ridges, Nature, 242, 137-139, 1973.

Parmentier, E.M., and D.W. Forsyth, Three-dimensional flow beneath a slow spreading ridge axis; a dynamic contribution to the deepening of the median valley toward fracture zones, $\mathrm{J}$. Geophys. Res., 90, 678-684, 1985.

Parmentier, E.M. and W.F. Haxby, Thermal stresses in the oceanic 1ithosphere: Evidence from geoid anomalies at fracture zones, J. Geophys. Res., 91, 7193-7204, 1986.

Parsons, B., and J.G. Sclater, An analysisof the variation of ocean floor bathymetry and heat flow with age, J.Geophys. Res., $\underline{82}$, $803-828,1977$

Pockalny, R.A., R.S. Detrick and P.J. Fox, The morphology and tectonics of the Kane Transform from Sea Beam bathymetry data, J. Geophys. Res. (Submitted), 1986.

Potts, C.G., R.S. White and K.E. Louden, Crustal structure of Atlantic fracture zones - II. The Vema fracture zone and transverse ridge, Geophys. J.R. astr. Soc., $86,491-513,1986$.

Purdy, G.M., P.D. Rabinowitz and J.J.A. Velterop, The Kane

Fracture Zone in the central Atlantic ocean, Earth Planet. Sci. Lett., $45,429-434,1979$.

Purdy, G.M., and R.S. Detrick, Crustal structure of the Mid-Atlantic Ridge at $23^{\prime} \mathrm{N}$ from seismic refraction studies, J. Geophys. Res., 91, $3734-3762,1986$. 
Labinowitz, P.D., G.M. Purdy, The Kane fracture zone in the western central Atlantic ocean, Earth Planet. Sci. Lett., 33, 2126, 1976.

Renard, V. and J.P. Allenou, Seabeam, multibeam echo-sounding in Jean Charcot: Description evaluation and first results, Int. Hydrogr. Rev. Monaco, 56, 35-67, 1979.

Robb, J.M., and M.F. Kane, Structure of the Vema Fracture Zone from Gravity and Magnetic Intensity profiles, J. Geophys. Res., 80 , 4441-4445, 1975.

Rona, P.A. and D.F. Gray, Structural behavior of fracture zones symmetric and asymmetric about a spreading axis: MidAtlantic Ridge (Latitude $23^{\prime}$ N to $27^{\prime}$ N), Geol. Soc. Am. Bull., 91, 485-494, 1980 .

Sandwe11, D.T., and G. Schubert, Lithospheric flexure at fracture zones, J. Geophys. Res., 87, 4657-4667, $1982 \mathrm{~b}$.

Sandwe11, D.T., Thermomechanical evolution of oceanic fracture zones, J. Geophys. Res., 89, 11401-11413, 1984.

Schouten, H., K.D. Klitgord, and J.A. Whithead, Segmentation of mid ocean ridges, Nature, in press, 1986.

Sclater, J.G., R.N. Anderson, and M.L. Bell, Elevation of ridges and evolution of the central eastern Pacific, J. Geophys. Res., 76, $7888-7915,1971$.

Sibuet, J-C., and B. Veyrat-Peinet, Gravimetric model of the Atlantic equatorial fracture zones, J. Geophys. Res., 85, 943-954, 1980.

Sinha, M.C., and K.E Louden, The Oceanographer Fracture Zone. 1. Crustal structure from seismic refraction studies, J.R. Astron. Soc., $\underline{75}, 713-736,1983$. 
sleep, N.H., and S. Biehler, Topography and tectonics at the

intersections of fracture zones and central rifts, J. Geophys. Res., 75, 2748-2752, 1970.

Stroup, J.B., P.J. Fox, Geologic investigations of the Cayman Trough:

Evidence for thin crust along the mid-Cayman Rise, J.Geo1., 89 , $395-420,1981$.

Sykes, L.R., Mechanism of earthquakes and nature of faulting on the Mid-Atlantic Ridge, J. Geophys. Res., 72, 2131-2153, 1967.

Talwani, M., J.L. Worzel, M. Landisman, Rapid gravity computations for two-dimensional bodies with application to the Mendocino submarine fracture zone, J. Geophys. Res., 64, 49-59, 1959.

Trehu, A.M., Depth vs. (age) $1 / 2$ : a perspective on mid-ocean rises, Earth Planet. Sc1. Lett., 27, 287-304, 1975.

Tucholke, B.E., and H. Schouten, Global plate motion changes recorded in the Kane Fracture Zone, Geol. Soc. Am. Abstr. Programs, 17, no. 7,1985 .

Turcotte, D.L., Are transform faults thermal contraction cracks?, J. Geophys. Res., 70, 2573-2577, 1976.

Turcotte, D.L. and G. Schubert, Geodynamics: application of continuum physics to geological problems, pp 450, Wiley, New York, 1982. Twigt, W., J. Verhoef, K. Rohr, Th. F.A. Mulder, and B.J. Collette, Topography, magnetics and gravity over the Kane fracture zone in the Cretaceous Magnetic Quiet Zone (African Plate), Geophysics, Proceedings B $\underline{86}$ (2), $181-210,1983$.

Van Ande1, T.H., J.D. Phillips, and R.P. Von Herzen, Rifting origin for the Vema Fracture in the north Atlantic, Earth Planet Sci. Lett., 5, 296-300, 1969. 
Van Ande1, T.H., R.P. Von Herzen, and J.D. Phillips, The Vema Fracture Zone and the tectonics of transverse shear zones in oceanic crustal plates, Mar. Geophys. Res., 1, 261-283, 1971. Van Andel, T.H., D.K. Rea, R.P. Von Herzen, and H. Hoskíns, Ascension Fracture Zone; Ascension island and the Mid-Atlantic Ridge, Geol. Soc. Am. Bu11., 84, 825-840, 1973.

Watts, A.B., J.H. Bodine, and M.S. Steckler, Observations of flexure and the state of stress in the oceanic 1ithosphere, J. Geophys. $\underline{\text { Res., }}$ 85, 6369-6376, 1980 .

Wilson, J.T., A new class of faults and their bearing on continental drift, Nature, $\underline{73}, 1959-1982,1965$.

White, R.S., R.S. Detrick, M.C. Sinha and M.H. Cormier, Anomalous seismic crustal structure of oceanic fracture zones, Geophys. J. R. astr. Soc., 79, 779-798, 1984 .

Whitmarsh, R.B., and A.S. Laughton, A long-range sonar study of the Mid-Atlantic Ridge crest near $37^{\prime} \mathrm{N}$ and its tectonic implications, Deep Sea Res., 23, 1005-1023.

Whitmarsh, R.B., and A.J. Calvert, Crustal structure of Atlantic fracture zones: I - The Charlie Gibbs FZ, Geophys. J. Roy. Astro. Soc., $85,107-138,1986$. 